\title{
A Versatile Soybean Recombinant Inbred Line Population Segregating for Low Linolenic Acid and Lipoxygenase Nulls - Molecular Characterization and Utility for Soymilk and Bioproduct Production
}

\author{
Yarmilla Reinprecht, Shun-Yan Luk-Labey and K. Peter Pauls \\ University of Guelph, Plant Agriculture, 50 Stone Road E, Guelph, ON N1G 2W1
}

Canada

\section{Introduction}

The chapter aims to: (a) review the development of a soybean recombinant inbred line (RIL) population obtained from the RG10 x OX948 cross that is segregating for low linolenic acid (LLA) and lipoxygenase nulls (3lx), (b) present the molecular characterization of the LLA and 3lx traits and (c) discuss the applicability of the population for soymilk and biocomposite production.

The chapter is organized as follows. Section 2 describes development and evaluation of the RG10 x OX948 RIL population, inheritance of LLA and 31x traits and the development of novel low linolenic acid, lipoxygenase free (LLA.3lx) germplasm. Section 3 describes the molecular characterization of the LLA and 3lx traits derived from RG10 and OX948, respectively. The versatility of the RIL population for different applications, including soymilk and bioproduct production are presented in Section 4, which illustrates that there is potential for utilizing the whole soybean plant. The conclusion summarizes the results and discusses possible future uses of the RG10 x OX948 RIL population.

Problem - Oxidation of linolenic acid (LA) is catalyzed by lipoxygenase (LX; linoleate: oxygen oxidoreductase; EC 1.13.11.12) and is associated with off-flavours of soybean products. The hydroperoxides that are produced and their breakdown products impart undesirable grassy-beany and bitter flavours on soybean products (Rackis et al., 1979). Most soybean cultivars contain 70 to $90 \mathrm{~g} \mathrm{~kg}^{-1} \mathrm{LA}$ and approximately $20 \mathrm{~g} \mathrm{~kg}^{-1}$ of the total seed protein is LX. A possible solution to soybean stability problems is to genetically eliminate seed LX and reduce the content of LA. A number of soybean cultivars with low LA content (LLA; < $40 \mathrm{~g} \mathrm{~kg}^{-1} \mathrm{LA}$ ) or seed LX nulls (Hammond et al., 1972; Hildebrand \& Hymowitz, 1982; Wilcox, 1985; White, 2000) have been developed. It was shown that oil extracted from LLA lines is more stable than oil extracted from conventional soybean, needs less hydrogenation and consequently, contains less unhealthy trans fatty acids (Mounts et al., 1988), which may reduce the risk of heart disease (Hayakawa et al., 2000). Similarly, protein products from lx3 soybean have more favourable flavour profiles (King et al., 1998). It has been suggested that a combination of seed LX nulls with LLA content might lead to even 
better tasting soybean protein products and oil with improved oxidative stability (Davies \& Nielsen, 1986). However, oil extracted from a line combining LX2 and LX3 nulls with less than $30 \mathrm{~g} \mathrm{~kg}^{-1}$ LA content did not show improved oxidative stability (Shen et al., 1996). To explore the potential for improving oil stability in soybean further we combined LX triple null $(l \times 1 l \times 2 l \times 3)$ from line OX948 with LLA content from lines RG10 (fan-b) and PI 361088B [fan(PI 361088B)] into new LLA.3lx soybean lines (Reinprecht et al., 2005; 2006a).

Inheritance - Different patterns of inheritance for LA have been reported including quantitative inheritance (Graef et al., 1988) or a combination of major and minor genes (Fehr et al., 1992). The LLA content in RG10 is simply inherited and controlled by homozygous recessive alleles with additive effects at the Fan locus (Stojsin et al., 1998). Different types of gene action for LA content, ranging from codominance to complete dominance, have been reported for different crosses (Rahman et al., 1998). Also, depending of cross, complete maternal inheritance of LA content (Martin et al., 1983), partial maternal effects (Graef et al., 1988), or the lack of a maternal effect (Rahman et al., 1998) have been observed. In addition, environmental conditions, especially temperature were reported to have effect on unsaturated fatty acid contents (Wolf et al., 1982).

Similarly, inheritance of seed LX is simple. A single distinct gene encodes each of the three seed isozymes. Nulls for LX are controlled by single recessive loci, named $l \times 1, l \times 2$ and $l \times 3$ (Hildebrand \& Hymowitz, 1982; Kitamura et al., 1983; Davies \& Nielsen, 1986). Lx1 and Lx2 are tightly linked whereas the inheritance of $L x 3$ is independent of $L x 1$ and $L x 2$ (Davies \& Nielsen, 1986), so that in 31x mutants, a two-gene inheritance pattern has been observed (Hajika et al., 1992). No maternal or cytoplasmic effects were reported (Hildebrand \& Hymowitz, 1982). The new LLA.3lx soybean lines were used to study the inheritance of LA and LX genes and to test for possible interactions between these traits (Reinprecht et al., 2005; 2006a).

Molecular basis of LLA and lx3 traits - In soybean seed, LA is synthesized predominantly in the endoplasmic reticulum (ER) by desaturation of linoleic acid (Cherif et al., 1975). The reaction is catalyzed by cytoplasmic, membrane-bound, $\omega-3$ fatty acid desaturase (E.C. 1.14.99.-), which introduces the third double bond in linoleic acid at the $\omega-3$ position. It was suggested that three microsomal $\omega-3$ fatty acid desaturase genes (GmFad3A, GmFad3B and GmFad3C) contribute to LA levels in soybean seed, with the GmFad3A (GmFad3-1b) being the most abundant (Bilyeu et al., 2003; Anai et al., 2005). Therefore, mutations in these genes could reduce the LA concentration in soybean seeds (Byrum et al., 1997; Bilyeu et al., 2005). A number of soybean breeding lines and cultivars with LLA content have been developed by mutagenesis and conventional breeding. The LA content in an ethyl methane sulfonate (EMS) mutant line C1640 ( $34 \mathrm{~g} \mathrm{~kg}^{-1}$, Wilcox et al., 1984) is controlled by a single recessive fan(C1640) allele at a major Fan locus (Wilcox \& Cavins, 1985), which encodes $\omega-3$ fatty acid desaturase (Brummer et al., 1995). The Fad3 gene, coding for $\omega-3$ fatty acid desaturase, was mapped to the same region (Byrum et al., 1995). The molecular basis of the LLA trait has been described in different backgrounds. The fan allele from the LLA line A5, initially associated with the full or partial deletion of an unknown microsomal $\omega-3$ desaturase gene (Byrum et al., 1997), was later assigned to the GmFad3A gene (Bilyeu et al., 2003). The mutated gene from the line M24 (X-ray mutant) corresponds to GmFad3B (GmFad3-1a) at the Fanx locus (Anai et al., 2005). Soybean line A29 has mutations in all three $\omega-3$ fatty acid desaturases (GmFad3A, GmFad3B and GmFad3C) and has a LA content of $10 \mathrm{~g} \mathrm{~kg}^{-1}$ (Bilyeu et al., 2006). RG10 is a LLA mutant line produced by EMS treatment of C1640. The LLA content in RG10 (less than $25 \mathrm{~g} \mathrm{~kg}^{-1}$ ) is simply inherited and controlled by homozygous 
recessive alleles at the Fan locus with additive effects. The RG10 allele was designated as fan$b$ (for a very low content of LA) by Stojsin et al. (1998). The objective of this study was to determine the molecular basis of the LLA trait in soybean mutant line RG10, developed by two rounds of EMS treatment.

Mature soybean seeds contain three LX isozymes, namely, LX1, LX2 and LX3 (Axelrod et al., 1981). The isozymes have different $\mathrm{pH}$ optima, substrate specificities and reaction products (Feussner \& Wasternack, 2002). Spontaneous mutants for single LX isozymes have been identified (Hildebrand and Hymowitz 1981; Kitamura, 1984) and a number of single, double (Kitamura et al., 1985) and 31x mutants were developed by gamma $(\gamma)$-irradiation (Hajika et al., 1991). The molecular basis for three seed LX nulls has been described in different backgrounds. Wang et al. (1994) identified a single amino acid replacement at H532Q (corresponds to H504 in LX1) in two triple null $\gamma$-mutant lines (Kyushu 111 and the $\mathrm{K}$ line) that resulted in an inactive LX2 isozyme. Two null alleles have been identified for the $L x 3$ gene. Two single nucleotide substitutions in the promoter region of $L x 3$ (mutation 2: $\mathrm{C}$ to $\mathrm{T}$ at -636 and mutation 1: $\mathrm{T}$ to $\mathrm{A}$ at -585$)$ in Kyushu 111 and the $\mathrm{K}$ line resulted in a complete null for that isozyme (Wang et al., 1995). The lines PI 205085, PI 417458 (Lx1Lx2lx3) and Jinpumkong 2 (lx1lx2lx3) have an $l \times 3-a$ allele, which is a frame shift mutation (single G deletion at the position 101 in exon 1) that introduces a stop codon and results in premature termination of protein translation (Lenis et al., 2010). Three null alleles have been reported for the $L x 1$ gene. The $l x 1-a$ allele (PI 408251) is a 74 bp deletion in exon 8 at position 2752, which introduces a stop codon and terminates protein synthesis after 524 amino acids. In addition to the same $74 \mathrm{bp}$ deletion, the $l x 1-c$ allele (Jinpumkong 2) contains seven substitutions and $3 \mathrm{bp}$ deletion at the $5^{\prime}$ end of the gene. A nonsense mutation C2880A in the $l x 1-b$ allele (PI 133226) results in an S568STOP change (Lenis et al., 2010). The objective of this work was to determine the molecular basis of the seed LX nulls in soybean mutant line OX948.

Many GenBank records of $\omega-3$ fatty acid desaturase (Fad3) and seed LX ( $L x 1, L \times 2$ and $L x 3$ ) genes exist. Recent release of a complete draft of soybean genome sequence opens new insights into genome organization of this ancient paleopolyploid (Schmutz et al., 2010). Four homologous regions containing $19 \mathrm{LX}$ genes are present in the soybean genome (Shin et al., 2008). Similarly, homology between GmFad3-1a (Fad3B) and GmFad3-1b (Fad3A) and between GmFad3-2a (Fad3C) and GmFad3-2b ('Fad3D') suggests that the $\omega-3$ fatty acid desaturase gene family in soybean may have developed through gene duplication (Anai et al., 2005).

LA and LX markers - Conventional methods like gas liquid chromatography (Bannon et al., 1987) and colorimetric assays (Suda et al., 1995), are convenient for screening lines for LA content and seed LX status in soybean breeding programs focussed on selecting cultivars with improved flavour. Both procedures can be performed on a small piece of the seed, leaving the rest of the seed for planting. However, the assays are time consuming and the colorimetric LX assays are subjective and cannot distinguish heterozygotes. In contrast, screening procedures based on codominant, gene-specific, markers for LLA and 3lx traits could increase the precision and efficiency of breeding for LLA.3lx soybean since the markers, which are environmentally neutral, can be determined quickly and accurately using DNA extracted from any small tissue sample. The use of marker-assisted selection (MAS) can accelerate and simplify breeding soybean with improved flavour. Kim et al. (2004) developed a single nucleotide polymorphism (SNP) marker for the $L x 2$ gene. Spencer et al. (2004) developed a simple sequence repeat (SSR) marker Satt534, while Sauer et al. (2008) developed Fad3A gene-based markers for LA content. Working with the LLA.31x RG10 x OX948 population, our group developed markers for LLA (SSR Satt534 and gene- 
based Fad3i6) and 31x (Lox1-3 and Lox3-HaeII) (Reinprecht, 2002; Reinprecht et al., 2006b), which have been used to simultaneously select for LLA and $31 \times$ ( $l \times 1 / l \times 2$ and $l \times 3$ ) phenotypes, thus accelerating selection for soybean lines for improved soymilk stability and flavour (Luk, 2006). The objectives of this work were to characterize previously developed gene-based markers and to develop additional markers based on mutations in newly sequenced $\omega-3$ fatty acid desaturase and LX genes.

Use of RIL population in soymilk study - Soymilk is a highly nutritious beverage but faces some consumer acceptance barriers because of objectionable flavours and odours (TorresPenaranda \& Reitmeier, 2001). It is made by grinding water-soaked soybeans with additional water. The liquid is separated from the okara (ground soybean) by filtration and then heat processed (Liu, 1997). The compounds that give soy its poor taste are believed to be breakdown products of the hydroperoxides formed during oxidation of polyunsaturated fatty acids, like linolenic acid (Dutton et al., 1951). Hydroperoxide formation is catalyzed by seed LX (Furata et al., 1996; Wilson, 1996). Hydrogenation has been used to improve both the flavour and stability of soybean oil (Dutton et al., 1951; Mounts et al., 1994) but studies have shown that oils produced by this process contain trans fatty acid isomers, which are associated with an increased risk of coronary heart disease when consumed for an extended period of time (Zock \& Katan, 1997). Studies on oil stability and flavour show that soybean oils with reduced LA content compared favourably to oils derived from conventional soybean cultivars (Mounts et al., 1988; Mounts et al., 1994). LX-free lines have also been shown to produce less of the volatiles responsible for the generation of off-flavours (Kobayashi et al., 1995; Furata et al., 1996).

The level of LA in soybean oil is typically $8 \%$ (or $80 \mathrm{~g} \mathrm{~kg}^{-1}$ ) but LLA soybean lines ( 2\%) have been produced that are comparable to conventional soybean lines for their agronomic and seed traits (Ross et al., 2000; Reinprecht et al 2005). It has been also suggested that the elimination of lipoxygenase from soy products would make them blander and more acceptable to consumers (Wilson, 1996). Lines from the LLA.3lx soybean RIL population were used to test the effects of LLA and lx3 traits on lipid oxidation and soymilk flavour (Luk, 2006).

Use of RIL population in composite study - Soybean is grown for it high value oil (20\%) and protein $(40 \%)$ seed. However, residues (stem and leaf) left after harvesting the seed are potential sources of significant amounts of low cost plant fibers. For every ton of grain harvested there is 3-5 times that weight in stem fibers. Although annually renewable and available in abundance, agricultural residues (including soybean) are of limited value at present and are usually discarded and left in the field to decompose (Sticklen, 2006). The use of crop residues for industrial applications could be an additional source of revenue for farmers. If only a portion (approximately 30\%) of the stems are collected this can be done without adversely affecting soil fertility (Lindstrom, 1986). Properties such as good mechanical performance, good formability, biodegradability, high sound absorption, low abrasiveness, low dermal and respiratory irritability and low density make plant fibers suitable for use as fillers and reinforcements in composite materials. Use of these materials has the potential to reduce the environmental impact of composite manufacture and reduce fuel consumption. Demands for lightweight car parts and good recycling possibilities ("green" car) are the main reasons for investigating the potential of using biofibers in the automotive industry. However, because of weak bonding between the fibers (hydrophilic) and the polymer matrices (hydrophobic), moisture sensitivity, odour emission, the relatively low processing temperatures that can be used and variation in the quality of biofibers the use of composites with plant fibers currently has limited applications to the car interior. 
Plant fibers are composed of cell wall materials. As a dicot, soybean has a type I primary cell wall, which consists of cellulose microfibrils buried in a matrix composed of hemicellulose (xyloglucan), pectin (homogalacturonan and rhamnogalacturonan) and protein (extensins and atabinogalactans). The interactions between the different polysaccharides provide the strength and flexibility of the cell wall (Hartholt et al., 2010). Secondary wall (synthesized after cell stops growing) contains mainly cellulose, hemicellulose and lignin (Yokoyama \& Nishitani, 2004).

Cellulose is a linear polymer of hydrogen-bonded $\beta$-(1,4)-linked glucose molecules organized in parallel crystalline layers, which form $3 \mathrm{~nm}$ thick microfibrils. Hydrogen bonds between different layers of the polysaccharides contribute to the resistance of crystalline cellulose to degradation (Sticklen, 2008). Primary cell wall microfibrils consist of approximately 8000 glucose molecules, while secondary cell wall may contain 15000 glucose molecules (Mutwil et al., 2008). Physical properties such as the crystalline state, degree of crystallinity and molecular weight are highly variable. Cellulose is synthesized in the plasma membrane by cellulose synthases (CesA) multimeric complexes arranged as hexagonal rosettes, each producing one microfibril of 36 glucan chains. Arabidopsis thaliana has at least 10 CesA genes with cell-specific expression patterns and functions. CesA1, CesA3 and CesA6 encode enzymes for primary wall cellulose biosynthesis, while CesA4, CesA7 and CesA 8 are expressed during secondary wall cellulose biosynthesis. Interactions between Ces $A$ and the cytoskeleton have important effects on cellulose fibril orientation and length (Somerville, 2006; Mutwil et al., 2008; Penning et al., 2009).

While cellulose has a relatively simple chemical structure, which is same for all plant species, hemicellulose is more complex. Hemicelluloses encompass a heterogeneous group of polysaccharides (including xylans, xyloglucans and (gluco)mannans) that have $\beta-(1,4)$ linked backbones (composed of various 5- and 6-carbon sugars such as arabinose, galactose, glucose, mannose and xylose) with equatorial configurations. Its structure differs among plant species and cell types. Dicot primary cell walls are composed mainly of xyloglucan $(20-25 \% \mathrm{w} / \mathrm{w})$ with small amounts of glucuronoarabinoxylan (5\%) and (gluco)mannan (3$5 \%)$. Glucuronoxylan is the major component $(20-30 \%)$ of secondary cell walls with the small amounts of xyloglucan, (gluco)mannan (2-5\%) and galactoglucomannan (0-3\%) (Scheller \& Ulvskov, 2010). Hemicelluloses are synthesized in the Golgi membranes by glycosyltransferases. The enzymes required for xyloglucan biosynthesis include $\alpha$-Larabinofuranosidase, xyloglucan endotransglucosylase, endo-xyloglucan transferase, $\beta$ mannosidase and $\beta$-galactosidase.

Pectin is structurally and functionally the most complex polysaccharide and it forms a gel matrix in the plant primary cell wall. Pectins are composed of highly complex family of polysaccharides rich in D-galacuronic acid. Cell walls contain different pectic polysaccharides including homogalacturonan (HG), xylogalacturonan (XGA), apiogalacturonan, rhamnogalacturonan (RGI) and rhamnogalacturonan II (RGII). Pectin is synthesized in the Golgi membranes and about 67 different glycosyltransferases, methyltransferases and acetyltransferases are required for these processes (Mohnen et al., 2008).

Lignin is a complex aromatic polymer composed of three major phenolic compounds, namely: $p$-coumoryl alcohol (H lignin), coniferyl alcohol (G lignin) and sinapyl alcohol (S lignin). Monolignol biosynthesis starts from the amino acid phenylalanine and proceeds through number of ring and side-chain modifications catalyzed by dozens of enzymes. The three monolignols differ from each other only by their degree of metoxylation. Peroxidase, laccase and dirigent proteins are involved in monolignol polymerization. The ratio of 
monolignols within the polymer varies between plant species, different tissues and cell wall layers (Boerjan et al., 2003).

Cell walls also contain proline-rich proteins, hydroxyproline-rich glycoproteins, arabinogalactan proteins, expansins, germin-like proteins, extensins, actin, 14-3-3-like proteins and laccase. Some of the cell wall modifying enzymes include: endo-1,4- $\beta-\mathrm{D}-$ glucanase, endo-1,3 1,4- $\beta$-D-glucanase, $\beta$-1,3-glucanase, $\beta$-galactosidase and cellulase.

Regulation of cell wall biosynthesis is complex. To build secondary cell walls, genes encoding cellulose, hemicellulose and lignin biosynthetic enzymes need to be coordinately expressed in a cell type specific manner. Secondary wall-associated NAC domain protein 1 (SND1) acts as a master switch turning on a subset of MYB and NAC transcription factors, which then activate the developmental machinery of secondary wall biosynthesis in fibers of Arabidopsis (Zhong \& Ye, 2007; Zhong et al., 2008).

Lignin and hemicellulose reduce the value of plant fibers for composite manufacture because, compared to cellulose, they degrade at different temperatures. Hemicellulose degrades at a lower temperature compared to cellulose while lignins with different monolignol components degrade at different temperatures. However, it has been shown that lignin compositions and amounts can be engineered to improve the processing efficiency of plant biomass (Vanholme et al., 2008). The interactions between lignin biosynthesis and other metabolic pathways as well as the cellulose and hemicellulose networks can also influence fiber traits. As pectin has roles in both primary and secondary cell walls, manipulation of pectin synthesis is expected to have diverse impacts on plant properties, including plant biomass (Mohnen, 2008). The principal aim of this work was to analyze the structure and properties of soybean stem fibers with a view to assessing their potential as additions for composites for the automotive industry. In order to simplify and accelerate future selection and/or molecular manipulation of plant fiber characteristics, the first step is to increase the information about the structural and regulatory genes that control the synthesis and modification of cell wall components (Reinprecht et al., 2010).

\section{RG10 x OX948 - LLA.3Ix RIL population}

\subsection{RIL population development and evaluation}

The soybean RIL population from the RG10 x OX948 cross was developed for a study to improve soybean oil and protein flavour. The population was derived from reciprocal crosses between a LLA line (RG10) and a 31x line (OX948) and consists of 169 RILs (Reinprecht et al., 2005). Mutant line RG10, used as the source for the LLA trait, was developed at the University of Guelph, Ridgetown Campus, Ridgetown, Ontario, Canada by chemical mutation of the LLA line C1640 (an ENS mutant of cultivar Century) with EMS (an EMS mutant of cultivar Century). The allele at the Fan locus in RG10 is designated as fan-b, for a very low content $(<25$ $\mathrm{g} \mathrm{kg}^{-1}$ ) of LA (Stojsin et al., 1998). The 3lx mutant line OX948 was developed at Agriculture and Agri-Food Canada, Greenhouse and Processing Crops Research Centre, Harrow, Ontario, Canada (Buzzell, unpublished). OX948 is a selection from a cross between Harovinton and a $31 \times F_{2}$ plant [produced by $\gamma$-irradiation; $F_{1}$ seed was obtained from Dr. Kitamura (National Agricultural Research Centre, Ministry of Agriculture, Forestry and Fisheries, Tsukuba, Japan)]. The 3lx line was selected at the $\mathrm{F}_{4}$ stage and included in yield trials. Both RG10 and OX948 were evaluated for yield and other agronomic characteristics. The parental lines were lower yielding compared to adapted commercial cultivars. 
Reciprocal crosses between RG10 (fan-bLx1Lx2Lx3) and OX948 (Fanlx1lx2lx3) were made in the growth room at the Department of Plant Agriculture, University of Guelph. The $F_{1}$ plants, segregating $\mathrm{F}_{2}$ plants and parents were evaluated under controlled indoor environments [16 h light $\left(200 \mu \mathrm{mol} \mathrm{m} \mathrm{m}^{-2} \mathrm{~s}^{-1}\right)$ and $8 \mathrm{~h}$ dark, 26 and $22^{\circ} \mathrm{C}$, respectively] in order to reduce possible environmental effects on fatty acid content. Single seed descent was used to accelerate inbreeding. A portion of a single seed $(\sim 2 / 3$ of the seed with embryo axis remaining after $1 / 3$ of the seed was removed and used to determine the fatty acid composition and presence of LX) from each $\mathrm{F}_{2}$ line was planted in a growth room using a 12 $\mathrm{h}$ day length until flowering, followed by a $16 \mathrm{~h}$ day length $\left(26^{\circ} \mathrm{C}\right.$ day and $22^{\circ} \mathrm{C}$ night $)$ with a light intensity of $500 \mu \mathrm{mol} \mathrm{m}^{-2} \mathrm{~s}^{-1}$, to produce $\mathrm{F}_{3}$ seeds. The identity of each $\mathrm{F}_{2}$ line and parent seeds was maintained during the inbreeding. The $\mathrm{F}_{3}$ seed was advanced to the $\mathrm{F}_{5}$ generation in Belize and the $\mathrm{F}_{5}$ lines were increased in single rows at Ridgetown and Harrow during the summer of 1999 (Reinprecht et al., 2006a).

The RIL populations [at the $\mathrm{F}_{6}$ and $\mathrm{F}_{7}$ stages together with parents and two check cultivars (OAC Bright and OAC Glencoe)] were evaluated for a number of seed and agronomic traits at three Ontario locations (Harrow, Ridgetown and Woodslee) in 2000 and 2001. The seed and agronomic characteristics of six LLA.31x $\left(<30 \mathrm{~g} \mathrm{~kg}^{-1} \mathrm{LA}\right.$ and all three seed LX enzymes absent) $\mathrm{F}_{7}$ lines together with the parents (RG10 and OX948) and eight lines/cultivars commonly grown in Ontario (OAC Bayfield, OAC Bright, OAC Glencoe, OAC Kent, OAC Oxford, 9163, RCAT Legacy and RCAT Staples) were evaluated in separate experiments at four Ontario locations (Harrow, Ridgetown, Woodslee and Woodstock) in 2001. Traits that were evaluated include: fatty acid composition (palmitic, stearic, oleic, linoleic and linolenic acid), presence of seed lipoxygenases (LX1, LX2 and LX3), days to flowering, days to maturity, plant height, plant lodging, seed yield, seed weight, oil and protein content. LX and fatty acid compositions were determined using a half-seed technique (Wilcox \& Cavins, 1985). Approximately one third of the cotyledon tissue distal from embryonic axis was used for fatty acid and LX analyses and the rest of seed was planted. Individual LX was assayed for two seeds of the parents, check cultivars and RILs by visually judging the outcome of a slightly modified colorimetric method (Suda et al., 1995). Fatty acid compositions were obtained by analyzing 10-seed bulks of parental, check cultivars, and $\mathrm{F}_{6}$ lines by gas liquid chromatography of fatty acid methyl esters according to the modified method of Bannon et al. (1987) using a Hewlett Packard 6890 Series gas chromatograph (Mississauga, ON), equipped with the J\&W BB-23 $15 \mathrm{~m} \times 250 \mu \mathrm{m} \times 0.25 \mu \mathrm{m}$ capillary column (J \& W Scientific, Folsom, CA).

Some seed and agronomic characteristics [averaged across six environments (three locations and two years)] for 169 RILs of the RG10 x OX948 population are shown in Table 1. Reduction of LA and removal of seed LX did not cause any obvious detrimental effects on agronomic traits including yield, indicating the possibility of developing productive soybean cultivars with high protein quality and oil stability (Reinprecht, 2002; Reinprecht et al., 2006b).

\subsection{Inheritance of LA and LX traits}

Reciprocal crosses between RG10 and OX948 were made and populations derived from them were evaluated for their fatty acid profiles and seed LX at the $F_{2}, F_{5}$ and $F_{6}$ generations. RG10 contains a single gene at a Fan locus that controls LA content with alleles acting in an additive manner (Stojsin et al., 1998). OX948 is normal line with more than $90 \mathrm{~g} \mathrm{~kg}^{-1} \mathrm{LA}$. In a RG10 $\mathrm{x}$ OX948 cross LA levels were determined by a single major gene with alleles acting in 


\begin{tabular}{|c|c|c|c|c|c|c|c|c|c|c|c|c|c|c|}
\hline Line & LA & $\mathrm{L}\rangle$ & & $\mathrm{H} / \mathrm{L}$ & Oil & Protein & Yield & Line & LA & LX & $\mathrm{H} / \mathrm{L}$ & Oil & Protein & Yield \\
\hline & & 12 & & & & & & & & 12 & & & & \\
\hline RG10 & 53.5 & ++ & & 38.1 & 188.3 & 01.6 & 2481.8 & RO88 & 119.7 & ++ & +24.8 & 179.0 & & 1553.5 \\
\hline X948 & 46.1 & - & - & 29.2 & 6.6 & & 374.0 & 89 & 65.2 & - - & 33.6 & 187.2 & & 58 \\
\hline RO1 & 58.2 & ++ & & 38.9 & 180.2 & 28.7 & 772.0 & O90 & 109.8 & - - & 28.8 & 177.5 & 5.8 & 321 \\
\hline RO2 & 78.7 & - - & & 30.4 & 186.7 & 20.2 & 504.0 & O91 & 124.9 & ++ & +37.6 & 182.3 & 9.7 & 42 \\
\hline RO3 & 116.2 & ++ & + & 34.2 & 181.3 & 410.7 & 2714.3 & RO92 & 67.8 & ++ & +32.2 & 171.7 & 26.0 & 298.7 \\
\hline RO4 & 138.3 & ++ & + & 25.3 & 184.8 & 414.5 & 3213.5 & RO93 & 56.0 & ++ & +35.6 & 182.5 & 415.2 & 917.3 \\
\hline RO5 & 62.1 & - & + & 30.0 & 182.0 & 424.3 & 2997.5 & RO94 & 114.1 & ++ & 33.4 & 183.7 & 411.8 & 590.5 \\
\hline RO6 & 120.8 & - & + & 40.7 & 187.8 & 410.0 & 2463.5 & RO95 & 128.7 & - & 37.2 & 186.0 & 20.7 & 123.8 \\
\hline RO7 & 64.1 & - - & & 37.7 & 180.7 & 429 & 797.0 & 096 & 134.6 & ++ & 24.5 & 179.8 & & 234.7 \\
\hline RO8 & 136.7 & -- & & 35.8 & 181.8 & & 501.0 & O97 & 35.4 & ++ & 34.3 & 186.7 & & 180.5 \\
\hline RO9 & 64.4 & - - & & 25.0 & 30.2 & & 33.8 & RO98 & 120.8 & - & - 23.8 & 189.3 & & 386.0 \\
\hline RO10 & 143.0 & - & + & 26.2 & 32.7 & & 625.7 & RO99 & NA & -- & + NA & NA & & NA \\
\hline RO11 & 84.7 & - & & 35.4 & 176.3 & & 17.0 & O100 & 69.9 & ++ & +32.5 & 178.2 & & 876.2 \\
\hline RO12 & 64.1 & ++ & & 35.7 & 174.7 & & 835.3 & O101 & 59.5 & ++ & +28.0 & 185.5 & & 322.1 \\
\hline RO13 & 65.8 & - & & 55.8 & 180.0 & & 248.0 & RO102 & 134.4 & ++ & +37.6 & 181.8 & & 600.5 \\
\hline RO14 & 62.0 & + & & 36.4 & 182.0 & 428.8 & 78.3 & O103 & 72.6 & - & - 42.4 & 180.3 & 37.7 & 820. \\
\hline RO15 & 138.0 & + & & 33.2 & 181.5 & 414.0 & 940.2 & O104 & 147.7 & - & 26.7 & 184.2 & 08.2 & 2391 \\
\hline O16 & 61.0 & + & + & 41.9 & 183.7 & & 49.8 & D105 & NA & ++ & NA & NA & & NA \\
\hline D17 & NA & ++ & + & 38.0 & 95.0 & 366 & & 06 & 42.9 & ++ & +52.8 & 193.8 & & 607.2 \\
\hline D19 & 48.4 & - - & & 32.2 & 33.3 & & & & 120.3 & ++ & 39.6 & & & 08.5 \\
\hline D20 & 72.6 & ++ & + & 30.8 & 71.5 & & & & 55.0 & ++ & +29.8 & 179.0 & & \\
\hline RO21 & 141.0 & ++ & + & 36.6 & 83.5 & & & & 49.4 & - - & 2.6 & & & 50.8 \\
\hline $\mathrm{O} 22$ & 3.0 & ++ & + & 26.7 & 3.5 & & & & 124.4 & ++ & +37.2 & 179.8 & & 306.2 \\
\hline & 41.4 & ++ & + & 32.0 & 77.0 & & & & 38.4 & ++ & +31.5 & 174.0 & & 537.3 \\
\hline 24 & 57.8 & +- & & 30.0 & 192.8 & & & & 65.8 & ++ & +26.8 & 179.0 & & 496.3 \\
\hline $\mathrm{O} 25$ & 74.2 & ++ & & 32.2 & 180.7 & & & & 46.5 & - - & 32.9 & 185.5 & & 669.2 \\
\hline RO26 & 123.8 & - & & 27.7 & 173.8 & & 210.3 & O114 & 36.1 & ++ & +37.5 & 175.7 & 30.8 & 3024 . \\
\hline RO27 & 68.2 & ++ & & 34.5 & 176.5 & & 60.8 & D115 & 50.9 & - - & 27.4 & 178.0 & & 550. \\
\hline RO28 & 122.2 & ++ & & 39.0 & 173.2 & 402 & 806.2 & O117 & 108.4 & - & +41.5 & 180.3 & 27.7 & $699 . \varepsilon$ \\
\hline RO29 & 143.2 & ++ & + & 30.9 & 186.7 & 409 & 315.7 & D118 & 65.0 & ++ & +27.6 & 182.0 & & 259.7 \\
\hline O30 & 116.8 & ++ & + & 33.5 & 175.2 & & $96.3^{3}$ & 120 & 104.8 & - & +39.7 & 185.3 & & 268.3 \\
\hline 031 & 48.3 & ++ & & 40.1 & 176.8 & & & 21 & 18.7 & - & 34.6 & & & 47. \\
\hline & 1.4 & - & & 36.2 & 185.2 & & & & 126.7 & ++ & 34.4 & 177.5 & & 7.5 \\
\hline & 0.7 & ++ & + & 33 & & & & & 110 & - & 35.6 & & & 5.3 \\
\hline & 139.0 & + & + & 26 & & & & & 115.4 & ++ & 32.0 & 183.3 & & $33.3^{3}$ \\
\hline & 63.0 & ++ & & 29 & & & & & 73 & ++ & +28.3 & & & 8.7 \\
\hline & 72.1 & - - & & 31 & 176 & & & & 93 & - - & .4 & 9.0 & & $0 . \varepsilon_{-}$ \\
\hline & 107.0 & - & & 25 & 174 & & & & 34.0 & ++ & 3.5 & & & 5. \\
\hline & & ++ & & 37 & 181 & & & & 62.8 & ++ & +33.9 & 178.3 & & 377. \\
\hline & 88.5 & ++ & & 45.8 & 180.3 & & & & 38.8 & ++ & +36.0 & 174.5 & & 2792. \\
\hline & 37.4 & ++ & & 52.4 & 179.3 & & 29.7 & & 122.3 & - & 36.6 & 184.0 & & 2575.2 \\
\hline & 61.4 & ++ & r & 39.0 & 180.7 & 418 & 976.3 & D131 & 103.2 & - & 35.5 & 179.8 & 14.5 & 3408.7 \\
\hline $\mathrm{R}$ & 98.9 & - & & 43.1 & 180.7 & & 168 & 0132 & 133.4 & - - & 30.1 & 186.5 & & 478.5 \\
\hline O43 & 38.6 & ++ & + & 32.0 & 172.5 & 420 & 3121.2 & O133 & 85.8 & - & 27.3 & 181.7 & & 2235.3 \\
\hline O44 & 122.2 & ++ & & 37.9 & 178.8 & 419 & 2611.3 & & 143.7 & +- & 36.6 & 176.2 & & 27.8 \\
\hline & NA & ++ & & NA & NA & & & & 62.6 & ++ & +27.1 & 183.8 & & 201.5 \\
\hline & 41.2 & - & & 34 & 185.7 & 422.7 & & & 91.0 & - - & - 25.2 & 180.5 & & 2893.7 \\
\hline & 82.5 & - & & 32.9 & 180.0 & & 2562.5 & & 66.2 & ++ & +33.4 & 179.3 & & $116.3^{3}$ \\
\hline & 70.3 & - & & 37.1 & 184.0 & & 297 & & 81.0 & $-\ldots$ & +28.4 & 185.2 & & 2518.0 \\
\hline RO49 & 60.4 & ++ & + & 30.6 & 185.5 & 410.3 & 2423.5 & RO139 & 63.1 & ++ & +21.7 & 178.5 & 424.7 & 1462.8 \\
\hline
\end{tabular}




\begin{tabular}{|c|c|c|c|c|c|c|c|c|c|c|c|c|c|c|}
\hline \multirow[t]{2}{*}{ Line } & \multirow[t]{2}{*}{ LA } & \multirow{2}{*}{\multicolumn{2}{|c|}{$\frac{\mathrm{LX}}{123}$}} & \multirow{2}{*}{$\mathrm{H} / \mathrm{L}$} & \multirow[t]{2}{*}{ Oil } & \multirow[t]{2}{*}{ Protein } & \multirow[t]{2}{*}{ Yield } & \multirow[t]{2}{*}{ Line } & \multirow[t]{2}{*}{ LA } & \multirow{2}{*}{$\frac{\mathrm{LX}}{123}$} & \multirow[t]{2}{*}{$\mathrm{H} / \mathrm{L}$} & \multirow[t]{2}{*}{ Oil } & \multirow[t]{2}{*}{ Protein } & \multirow[t]{2}{*}{ Yield } \\
\hline & & & & & & & & & & & & & & \\
\hline RO50 & 54.7 & ++ & + & 30.5 & 183.5 & 20.5 & 2813.7 & RO140 & 57.6 & --+ & 38.6 & 188.0 & 19.7 & 477.2 \\
\hline RO51 & 72.5 & ++ & +2 & 25.8 & & & 13.2 & & & --+ & & & & \\
\hline O52 & .0 & ++ & +3 & & & 6.8 & 03.0 & 42 & 90.8 & --+ & & & & 86.0 \\
\hline RO53 & 2.6 & - - & + & 29.4 & 6.2 & 8.7 & 59.0 & O143 & 133.8 & +++ & 32.1 & 85.8 & 6.2 & 96.7 \\
\hline RO54 & & ++ & + & 35.0 & 1.0 & & 35.0 & 44 & 47.0 & +++ & 21.0 & 81.2 & & 570.8 \\
\hline RO55 & 7.0 & ++ & +4 & 45.0 & 7.7 & 9.7 & 26.5 & & 64.4 & +++ & 36.1 & 30.5 & & 29.0 \\
\hline RO56 & 2.3 & ++ & +3 & 32.2 & 185.7 & 11.5 & 670.8 & & 83.5 & --+ & 29.1 & 179.3 & & 68.8 \\
\hline RO57 & 47.1 & ++ & +2 & 29.0 & 30.7 & 418.3 & 2677.0 & 47 & 60.4 & +++ & 51.0 & 177.7 & & 101.0 \\
\hline O58 & 37.9 & ++ & +2 & 25.8 & 181.5 & 12.2 & 2371.0 & RO148 & 127.2 & +++ & 32.7 & 184.5 & .7 & 400.7 \\
\hline D59 & NA & ++ & +1 & NA & JA & & NA & & 105.9 & +++ & 30.6 & 181.3 & & 601.0 \\
\hline O60 & 55.9 & +- & +3 & 34.9 & 178.5 & & 3378.8 & & 35.1 & --+ & 35.5 & 178.0 & & 978.3 \\
\hline O61 & 142.1 & ++ & +3 & 30.3 & & & 54.5 & & 125.3 & +++ & 0.2 & & & 693.5 \\
\hline D62 & 60.9 & ++ & +4 & 48.8 & & & 05.5 & & 14.2 & +++ & .0 & 30.2 & & 993.7 \\
\hline D63 & 33.6 & ++ & +2 & 25.7 & & & 99.3 & & 136.9 & +++ & .7 & 75.7 & & 16.7 \\
\hline & 38.2 & ++ & +3 & 38.2 & & & 3302.2 & & 67.8 & +++ & .3 & 176.3 & & 414.8 \\
\hline 566 & 39.3 & + & +2 & 27.5 & 17 & & 2236.0 & & 89.3 & --+ & 31.9 & 179.5 & & 133.0 \\
\hline O67 & 72.8 & + & +2 & 28.1 & 177.7 & 8.3 & 3296.7 & & 101.4 & - & 29.7 & 182.3 & 6.5 & 063.8 \\
\hline O68 & 122.1 & ++ & +2 & 23.9 & 32.5 & 1.0 & 3031.3 & & 119.5 & +++ & 28.4 & 186.3 & 0.8 & 2000.8 \\
\hline O69 & 36.3 & + & +3 & 32.7 & 175.0 & 18.7 & 3246.0 & O158 & 121.0 & +++ & 31.5 & 181.7 & 14.5 & 2477.7 \\
\hline O70 & 76.3 & - & -2 & 28.4 & 176.8 & 38.7 & 2191.2 & O159 & 126.1 & +++ & 41.5 & 182.5 & 26.8 & 2905.3 \\
\hline O71 & 118.8 & ++ & +4 & 42.8 & 187.3 & 1.5 & 2338.8 & D160 & 59.1 & --+ & 31.5 & 184.3 & 9.5 & 2600.5 \\
\hline D72 & 20.0 & - - & +2 & 29.4 & 5.7 & & 2273.5 & & 67.2 & - - & 26.0 & 176.2 & & 2453.7 \\
\hline 973 & 40.5 & - & +2 & 27.6 & 5.0 & & 2718.8 & & 35.0 & - - & 37.8 & 184.0 & 6.0 & 2934.0 \\
\hline RO75 & 108.0 & ++ & +2 & 29.3 & 1.3 & & 44.7 & & 38.9 & --+ & 37.8 & 179.0 & & 3211.5 \\
\hline RO76 & 76.1 & ++ & +2 & 29.7 & 0 & & 7.0 & & 61.6 & +++ & 33.0 & 178.8 & & 30.2 \\
\hline & 119.8 & - - & -3 & 34.1 & 17 & & 5.0 & & 34.0 & +++ & 9.9 & 180.0 & & 95.3 \\
\hline & & ++ & +3 & 35.0 & 17 & & & & 50.3 & -- & & & & 52.2 \\
\hline 979 & 150 & ++ & +3 & 36.7 & 176 & & 3224.5 & & 63.8 & --+ & 42.8 & 5.2 & & 5.3 \\
\hline O80 & 127.7 & - - & -3 & 39.5 & 18 & & 2569.7 & & 135.0 & +++ & 32.2 & 179.2 & & 2879.7 \\
\hline O81 & 139.1 & - & +3 & 35.3 & 18 & 410 & 3211.5 & & 74.3 & +++ & 42.3 & 176.3 & 23.2 & 2921.8 \\
\hline D82 & 24.2 & - - & -3 & 31.7 & & & 08.8 & & 63.6 & +++ & 31.1 & 183.5 & 31.8 & 2335.7 \\
\hline D83 & 2.7 & ++ & +2 & 24.3 & 180 & 37 & 1921.8 & RO171 & 41.7 & +++ & 36.7 & 184.3 & 14.8 & 2666.3 \\
\hline D84 & 43.6 & ++ & +3 & 34.3 & 180 & & 3163.7 & RO172 & 38.4 & +++ & 37.9 & 174.2 & 16.7 & 2818.5 \\
\hline D85 & 61.3 & - & +3 & 32.7 & 173 & & 3552.5 & RO173 & 124.9 & --+ & 31.6 & 179.0 & 419.5 & 2369.7 \\
\hline O86 & 85.0 & - - & +2 & 24.5 & 191.2 & 418.8 & 2022.5 & RO174 & 93.1 & --+ & 30.1 & 180.8 & 423.8 & 2557.2 \\
\hline RO87 & 63.0 & - & +3 & 36.7 & 174.3 & 417.7 & 2365.7 & & & & & & & \\
\hline
\end{tabular}

LA, linolenic acid content ( $\left.\mathrm{g} \mathrm{kg}^{-1}\right)$; LX, seed lipoxygenase (+, present; - , absent); H/L, height/lodging index trait (cm/ unit of lodging); Oil, oil content ( $\mathrm{g} \mathrm{kg}^{-1}$, on dry weight basis); Protein content ( $\mathrm{g} \mathrm{kg}^{-1}$, on dry weight basis); Yield ( $\mathrm{kg} \mathrm{ha}^{-1}$, based on $13 \%$ moisture)

Table 1. Seed and agronomic characteristics of RG10 x OX948 population (averaged across three locations and two years)

an additive manner. However, evidence for the presence of minor genes in this material interacting with the major gene was observed. These results might explain the transgressive segregants that were observed at the high end of the LA content distribution for the $F_{2}$ population from this cross (Reinprecht et al., 2005). No significant cytoplasmic effects were observed on LA content. The LLA trait was highly heritable and stable in different environments (Belize and Ontario, Canada). The three seed LX were each controlled by 
single genes in RG10 x OX948 crosses. No significant correlations were observed between LA content and seed LX.

\subsection{Novel LLA.31x germplasm}

Several RILs that combine LLA content $\left(<35 \mathrm{~g} \mathrm{~kg}^{-1}\right)$ with $31 \mathrm{x}$ were obtained from RG10 $\mathrm{x}$ OX948 reciprocal crosses and evaluated for a number of seed and agronomic traits at four Ontario (Canada) locations (Harrow, Ridgetown, Woodslee and Woodstock) in 2001 (Reinprecht et al., 2006a). The LLA.3lx lines (RO115, RO162, OR265, OR297, OR315 and OR322) had higher than average seed weight and protein content, but were 21 to $31 \%$ lower yielding than typical cultivars for these regions. Compared with parental lines, the LLA.31x lines were 5 to $18 \%$ lower yielding. However, comparisons of LLA.3lx lines with lines combining high LA and all three seed LX (HLA.3LX) indicated no yield difference between the two groups of lines in these populations. The results suggest that it should be possible to use this novel germplasm to develop competitive soybean cultivars that are resistant to oxidative degradation (Reinprecht et al., 2006a).

\section{3. $\omega-3$ fatty acid desaturase (Fad3) genes and three LX genes in RG10 and OX948}

\subsection{Linkage/QTL map}

$\mathrm{F}_{5}$ RILs from the RG10 x OX948 cross were genotyped for simple sequence repeats (SSR), random amplified polymorphic DNA (RAPD), sequence tagged sites (STS), and cleaved amplified polymorphic sequences (CAPS) markers and evaluated for seed and agronomic traits at three Ontario locations in two years. Linkage analysis was performed using Mapmaker/EXP version 3.0b (Lander et al., 1987). A minimum LOD score of 3.0 and maximum distance between two markers of $50.0 \mathrm{cM}$ were used to assign loci into linkage groups. Recombination frequencies were converted to $\mathrm{cM}$ distances using Kosambi's mapping function (Kosambi, 1944). The RG10 x OX948 map was compared with soybean composite_2003 genetic map (http://soybase.org). QTL analysis was performed with composite interval mapping (CIM) using QTL Cartographer version 2.00 (Wang et al., 20012004). Genome-wide scans were performed for each trait and QTL were declared significant if their LOD threshold values were $\geq 2.0$.

One hundred and twenty markers covering $1247.5 \mathrm{cM}$ were mapped to 18 linkage groups (LG) in the soybean composite genetic map (Reinprecht, 2002; Reinprecht et al., 2006b). Seed LX $L x 1$ and $L x 2$ mapped as single major genes to adjacent locations $0.2 \mathrm{cM}$ apart on chromosome 13 (LG F), which confirms their previous location (Davies \& Nielsen, 1986). Lx3 mapped to chromosome 15 (LG E). A major quantitative trait locus (QTL) associated with reduced LA content was identified on chromosome 14 (LG B2). QTL for 12 additional seed and agronomic traits were detected. LA content, linoleic acid content, yield, seed weight, protein content and plant height QTL were present in at least four of six environments. Three to eight QTL per trait were detected that accounted for up to $78 \%$ of total traits variation (Reinprecht, 2002; Reinprecht et al., 2006b). LA and LX loci did not overlap yield QTL, suggesting that it should be possible to develop high yielding cultivars that are resistant to oxidative degradation by MAS.

\subsection{Molecular basis of LLA and 3Ix traits}

An understanding of the molecular bases of the LLA trait in RG10 and the 31x trait in OX948 can facilitate breeding efforts of soybean with RG10-type and/or OX948-type of oxidative 
stability. In order to determine the molecular bases of the LLA and 3lx traits, four $\omega-3$ fatty acid desaturases (Fad3A, Fad3B, Fad3C and Fad3D) and three LX genes (Lx1, Lx2 and Lx3) were sequenced in RG10 and OX948. The mutations in Fad3A gene (same as C1640) and the first characterized mutation in Fad3B gene, make RG10 an attractive source of the LLA trait (Reinprecht et al., 2009). A potential immediate use of RG10 (or its derivatives) is to produce very low LA content soybeans by crossing with lines containing the fan mutation only. Alternatively, extremely low LA (10 g kg-1 or less) lines could be derived from RG10 directly by mutating the Fad3C gene it carries with an additional EMS treatment. Also, since we have identified the molecular bases of the mutations in three LX genes in OX948 it is becoming more attractive source of the 3lx trait. Furthermore, because the simple and independent inheritance of these traits has been demonstrated in the LLA.3lx RIL population these lines should be an attractive breeding material for soybean cultivars with high oxidative stability.

\subsubsection{Mutation in Fad3 genes}

The LLA line RG10 has reduced level of linolenic acid $\left(<25 \mathrm{~g} \mathrm{~kg}^{-1}\right)$, increased level of linoleic acid $\left(18: 2,650 \mathrm{~g} \mathrm{~kg}^{-1}\right)$ and decreased level of relative $\omega-3$ (18:2D) desaturation $\{3 \%$, calculated as $18: 2 \mathrm{D}=[(18: 3) /(18: 2+18: 3)] \times 100\}$ compared to normal line OX948 $\left(>60 \mathrm{~g} \mathrm{~kg}^{-1}, 510 \mathrm{~g} \mathrm{~kg}-\right.$ $1,20 \%)$. A strong negative correlation between the linolenic and linoleic acid, consistent with the decrease in relative 18:2D activity was also observed in $F_{2}, F_{5}$ and $F_{6}$ generations of the RG10 x OX948 crosses (Reinprecht et al. 2005). These results suggest that the lower LA content in RG10 and its derivatives resulted from partial inactivation of $\omega-3$ fatty acid desaturase and provides an additional evidence of the role of the Fad 3 genes in the expression of RG10 phenotype.

RG10 was developed by a two-step EMS mutagenesis process. The initial EMS treatment of the cultivar Century (approximately $70 \mathrm{~g} \mathrm{~kg}^{-1}$ of linolenic acid) produced line C1640 (Wilcox et al., 1984) with the mutation at the Fad3A $\omega-3$ fatty acid deasturase gene (Chappel \& Bilyeu, 2006) resulting in about $50 \%$ reduction of LA content $\left(34 \mathrm{~g} \mathrm{~kg}^{-1}\right)$. Further reduction of LA (approximately 30\%) to less then $25 \mathrm{~g} \mathrm{~kg}^{-1}$, was achieved by mutating the Fad3B gene of C1640 by the EMS treatment to produce RG10 (Reinprecht et al., 2009). Therefore, RG10 has the first mutation in the Fad3A gene [same as C1640, fan (C1640) allele] and the second mutation in the Fad3B gene (fan- $b$ allele).

Sequence analyses of mutant RG10 and wild-type OX948 $\omega-3$ fatty acid desaturase genes showed that the low level of linolenic acid in RG10 is likely a result of mutations in two Fad3 genes. For Fad3A the premature stop at the 798 position of the coding sequence (cDNA GenBank accession AY204710) would lead to a truncated protein that would not likely function as an active enzyme because it would be missing the third histidine box involved in the catalytic site of the enzyme (Schmidt et al., 1994) and C-terminus for ER localization. Similarly, the incomplete translation of the Fad3B transcript that would result from the splicing disruption could also lead to an inactive enzyme. This would leave only a functional Fad3C gene product in RG10 seeds [since Fad3-2b (Fad3D) is not generally active in seeds] and is likely the reason it contains less than $25 \mathrm{~g} \mathrm{~kg}^{-1}$.

Mutations in both Fad $3 \mathrm{~A}$ and Fad3B genes contribute to the reduced level of linolenic acid in the RG10 line. In the RG10 x OX948 population, both Fad3A and Fad3B gene mutations were present only in lines with less than $35 \mathrm{~g} \mathrm{~kg}^{-1}$ of linolenic acid (data not shown). These support results of our previous genetic studies of the LLA trait in RG10 that suggested additive gene action (Reinprecht et al., 2005). In particular, the detection of the mutation in 
the Fad3B gene in RG10 can explain the presence of additional minor gene(s) in RG10 $x$ OX948 population that interact with the major Fan (Fad3A) allele (Reinprecht et al., 2005). This is further supported by the presence of minor LA QTL on chromosomes 9 (LG K) and 15 (LG K) in addition to the major QTL mapped to the Fan region on chromosome 14 (LG B2) (Reinprecht et al., 2006a). In addition, a Fad3A mutation-based marker developed in the current study explain the majority (approximately 60\%) of the variability for the LA level in RG10 x OX948 population and maps in a major LA QTL in Fan region on chromosome 14 (LG B2). On the other hand, the Fad3B-based mutation identified in this study explains only $7 \%$ variability for the trait. This may explain why a cross between RG10 and C1640 indicated that a single gene controls the mutation in RG10 and that C1640 and RG10 have different alleles acting in an additive manner (Stojsin et al., 1998) and a second cross between RG10 and Century confirmed that the mutation in RG10 occurred at the Fan locus (Stojsin et al., 1998). Determination of the map location of Fad3B gene is underway.

\subsubsection{Mutation in LX genes}

The pedigree of OX948 includes an unnamed 31x source produced by $\gamma$-irradiation. The status of LX null alleles in OX948 has not been previously investigated. This study identified molecular differences in three LX genes between OX948 and a soybean genotype with normal LX level (RG10) that explain the null LX phenotypes in the mutant. Sequence analyses of mutant OX948 and wild-type RG10 $L x 1$ and $L x 2$ genes showed that the mutations were affecting highly conserved group of 6 histidines necessary for enzymatic activity. The mutation in $L x 1$ gene is a 74 bp deletion in exon 8 , which introduces stop codon that would prematurely terminate translation. A single $\mathrm{T}$ to A substitution in $L x 2$ gene changes histidine H532 (one of the iron-binding ligands essential for LX2 activity) to glutamine. The mutation in $L x 3$ gene is in the promoter region and represents two single base substitutions in a cis-acting AAATAC paired-box. All three mutations would result in the loss of LX in mature seed. In conclusion, the seed 31x trait in OX948 is caused by the $l \times 1-a$ (Lenis et al., 2010), $l \times 2-a$ (Wang et al., 1994) and $l \times 3$ (Wang et al., 1995) null alleles. However, when complete sequences for all three LX genes were compared to the published null allele sequences, the OX948 alleles also contain some unique features: Lx1 - 5' UTR and 3' UTR; Lx2 - 5' UTR, 3' UTR and SNPs in several introns; Lx3 - one deletion and five SNPs at 5' UTR (Reinprecht et al., 2011).

\subsection{Gene-based markers for LLA and Ix3 traits}

The results from these studies were also an excellent starting point for the development of gene-specific molecular markers. Several markers were developed for $\omega-3$ fatty acid desaturase alleles leading to low levels of LA (Reinprecht et al., 2009) and three seed LX nulls in soybean seed (Reinprecht et al., 2011). These markers are useful to distinguish between the presence and absence of seed LX (LX1 + LX2 and LX3) as well between the high and low LA levels in a wide range of Ontario soybean germplasm.

Two single nucleotide polymorphism (SNP) markers were developed for LLA (Fad3Ae6SNP and Fad3B-i5SNP) and two STS and one CAPS markers were developed for LX null (Lox1-3, Lox2-P1 and Lox3-HaeII) mutations (Table 2). Selection of cultivars with low levels of LA and free of seed LX but independent of screening with gas chromatography and colorimetric assays is an important parameter in breeding soybean cultivars with improved flavour stability. Rapid gel-based LLA and 3lx marker assays developed in these studies 
should simplify and accelerate introgression of the RG10-based LLA trait and/or OX948based 3lx (or their LLA.3lx derivatives) into elite soybean cultivars.

\begin{tabular}{|c|c|c|c|c|c|c|}
\hline \multirow[b]{2}{*}{ Trait } & \multirow[b]{2}{*}{ Gene } & \multirow[b]{2}{*}{ Marker } & \multicolumn{2}{|l|}{ Primer } & \multicolumn{2}{|c|}{ PCR product (bp) } \\
\hline & & & Sequence $5^{\prime}$ to $3^{\prime}$ & $\begin{array}{c}\mathrm{T} \\
\left({ }^{\circ} \mathrm{C}\right)\end{array}$ & RG10 & OX948 \\
\hline \multirow{2}{*}{ LA } & Fad3A & $\begin{array}{l}\text { Fad3A- } \\
\text { e6SNP }\end{array}$ & $\begin{array}{l}\text { CATCATCAGAAACTGCCTTGA } \\
\text { CGAGGTGATAATGAGGAATTT }\end{array}$ & 66 & 1250 & missing \\
\hline & Fad3B & $\begin{array}{l}\text { Fad3B- } \\
\text { i5SNP }\end{array}$ & $\begin{array}{l}\text { GCTCTATGGAATTCCATATTGGA } \\
\text { GTGACCATGGTGATGCAAGT }\end{array}$ & 65 & 2100 & missing \\
\hline \multirow{3}{*}{ LX } & $L x 1$ & Lox1-3 & $\begin{array}{c}\text { GCAATCTATGGTGATCAAAG } \\
\text { ATAGTCCTCTATCAGAAGACGAAC }\end{array}$ & 60 & 1032 & 958 \\
\hline & $L x 2$ & $\begin{array}{l}\text { Lox2- } \\
\text { P1 }\end{array}$ & $\begin{array}{l}\text { TTTCGATCTTGGCGTTCTTC } \\
\text { CCTCATCAACACCACTGTCC }\end{array}$ & 60 & 1158 & 1270 \\
\hline & $L x 3$ & $\begin{array}{l}\text { Lox3- } \\
\text { HAEIII }\end{array}$ & $\begin{array}{l}\text { AGTTCCCTCCACGAAGCAAG } \\
\text { CTTGTCTCCATGACCCACCT }\end{array}$ & 60 & $754+469$ & $374 / 380+469$ \\
\hline
\end{tabular}

Table 2. Linolenic acid (LA) and seed lipoxygenase (LX) gene-specific markers

\section{Use of RG10 x OX948 RILs for soymilk and bioproduct production}

\subsection{Use of LLA.3Ix lines from RG10 x OX948 reciprocal crosses for soymilk production}

To evaluate the effects of the combination of LLA and 3lx traits on soymilk quality the biochemical and sensory characteristics of soymilk made from OR297, a LLa.31x soybean, was compared to soymilk made from its parents (OX948, a 3lx line, and RG10, a LLA line), a standard soymilk cultivar (Harovinton) and a standard oilseed cultivar (OAC Kent).

\subsubsection{Soymilk palatability}

An evaluation of the soymilk samples produced from OX948, RG10, OR297, Harovinton, and OAC Kent was conducted by a 28 -member sensory panel. The protocol for soymilk production was obtained from J. Jenkinson (First Line Seeds). Two methods of soymilk production were employed. A 'hot' method, which involves an incubation of finely ground soybeans in $1 \mathrm{~L}$ of $96^{\circ} \mathrm{C}$ water for 30 minutes and a 'cold' method, which involves the incubation of finely ground soybeans in $200 \mathrm{~mL}$ of $22^{\circ} \mathrm{C}$ water for 20 minutes followed by an incubation of the mixture in $800 \mathrm{~mL}$ of $96^{\circ} \mathrm{C}$ water for 30 minutes. Both methods were used to prepare soymilk from OAC Kent. Only the cold method was used to prepare soymilk from OX948, RG10, OR297, Harovinton and OAC Kent. The hot method was used to inactivate LX activity, thus giving a more palatable soymilk control. The cold method tends to accentuate differences in stability between samples. OAC Kent was prepared using both methods and served as a control sample to aid in the identification of panelists who were not able to distinguish between soymilk samples.

Panelists were recruited from the University of Guelph community. Following a training session, panelists were asked to evaluate the six soymilk samples at three separate sessions over a three-week period. For each sample evaluated, panelists provided a written description as well as rankings for individual characteristics (i.e., beaniness, sourness, sweetness, rancidity, bitterness and nuttiness). Figure 1 depicts the panel's average ranking 
of the five cultivars/ lines of soymilk, for a variety of descriptors. For Green/Beany and Grainy/Nutty the LLA.3lx line (OR297) ranked significantly better than the standard soymilk cultivar included in the test (Harovinton).

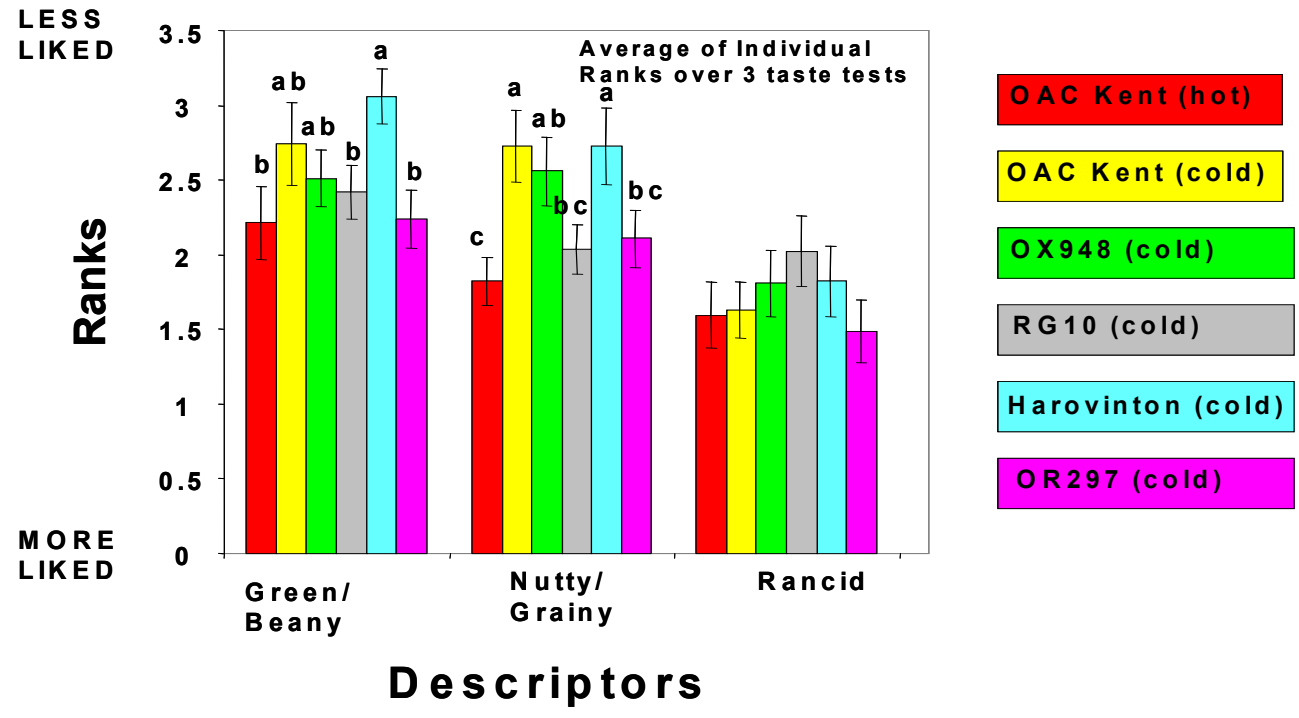

Fig. 1. Ranking of the soymilk samples prepared from five soybean cultivars over three tastings by 28 panelists for various descriptors. Means+/- SE are shown. Soymilk samples labelled with the same letter were not significantly different according to a LSD $(\mathrm{P}=0.05)$.

\subsubsection{Soybean and soymilk compositions}

To test for correlations between sensory evaluations and chemical compositions of the five soybeans cultivars/ lines used in the taste evaluation they were analyzed for total free sugar, total oil, and total protein compositions and lipid oxidation. Raw bean samples of OAC Kent, OX948, RG10, OR297 and Harovinton were analyzed prior to their use for soymilk preparation.

The LA levels of RG10 and OR297 were one-quarter of those measured for Harovinton, which is a tofu-type cultivar. OX948, the 31x parent of OR297, had the highest LA level $(11.0 \%)$ among the cultivars/ lines examined. OAC Kent, an oilseed cultivar, had the lowest protein content $(42.5 \%)$ but had the second highest oil content of all of the cultivars/ lines examined. The sucrose and total free sugar contents in OAC Kent and OR297 were approximately $10 \%$ higher than in all of the other cultivars/ lines that were tested.

The largest differences among soymilks at the time of serving to the taste panel $(20.5 \mathrm{hrs}$ after preparation) were observed in their malondialdehyde (MDA) levels. The amount of fatty acid oxidation that occurred in the soymilk samples was measured using the thiobarbituric acidreactive-substances (TBARS) assay described by Wills (1964) and Pedersen et al. (1973) with modifications from Buege \& Aust (1978) and Woodrow \& Luk (unpublished) to adapt the test to soymilk samples. The oxidation of polyunsaturated fatty acids produces MDA. 


\begin{tabular}{|c|c|c|c|c|c|}
\hline Sample ID & OAC Kent & Harovinton & OX948 & RG10 & OR297 \\
\hline LX status a & $+/+$ & $+/+$ & $-/-$ & $+/+$ & $-/-$ \\
\hline$\%$ LA a & $6.2 \pm 0.31$ & $9.5 \pm 0.35$ & $11.0 \pm 0.34$ & $2.1 \pm 0.08$ & $2.6 \pm 0.06$ \\
\hline$\%$ protein $b$ & 42.5 & 46.7 & 46.6 & 45.9 & 46.7 \\
\hline$\%$ oil b & 20.6 & 20.0 & 19.2 & 20.9 & 19.8 \\
\hline$\%$ dry matter $b$ & 94.3 & 93.5 & 93.5 & 93.8 & 93.7 \\
\hline$\%$ moisture $b$ & 5.7 & 6.5 & 6.5 & 6.2 & 6.3 \\
\hline$\%$ sucrose ${ }^{b}$ & 6.8 & 6.1 & 6.6 & 5.6 & 6.9 \\
\hline$\%$ raffinose $^{b}$ & 1.1 & 1.2 & 1.0 & 0.9 & 0.8 \\
\hline$\%$ stachyose ${ }^{b}$ & 4.0 & 3.7 & 4.2 & 4.1 & 4.2 \\
\hline$\%$ raffinose + stachyose $b$ & 5.4 & 5.2 & 4.8 & 5.0 & 5.1 \\
\hline$\%$ total free sugars $b$ & 11.9 & 11.1 & 11.7 & 10.6 & 12.1 \\
\hline \% hydrolysable carbohydrates b & 18.5 & 16.7 & 18.3 & 16.7 & 18.2 \\
\hline
\end{tabular}

${ }^{a}$ performed on seed extracts $(n=5, \pm$ SEM)

${ }^{b}$ performed on whole seeds $(\mathrm{n}=1)$

Table 3. Raw bean composition of OAC Kent, OX948, RG10, OR297 and Harovinton. Lipoxygenase (LX) status and percent of linolenic acid (LA) were determined by colorimetric assay and gas liquid chromatography, respectively. Protein, oil, dry matter, moisture, sucrose, raffinose, stachyose, raffinose and stachyose, total sugars and hydrolysable carbohydrates (free and bound sugars) were determined in whole seed samples using the FOSS NIRSystems (Soy Analyzer, Model No. 6500).

The interaction of MDA with two molecules of TBA generates a red TBA-MDA chromagen absorbing at $535 \mathrm{~nm}$. Polyunsaturated fatty acid oxidation activity can therefore be inferred by measuring the absorbance of the red compound after the reaction of MDA with TBA has taken place (Buege \& Aust, 1978; Hodges et al., 1999).

The soymilk prepared from OAC Kent using the hot method had approximately one-third the MDA levels of all the other samples. The reduction in lipid oxidation activity was expected since the heat treatment was used to denature proteins like LX, which catalyze the lipid oxidation process. In the current study, the soymilk prepared by the hot method was included as a control sample with relatively low lipid oxidation activity. Heat treatment is used in commercial soymilk production to reduce the generation of rancid flavours (Wolf, 1975; Davies et al., 1987; Kitamura, 1993; Wilson, 1996). The limitation with this approach is that it leads to other changes in the composition of the soymilk, such as protein denaturation and lipid hydrolysis. This was observed in the current study as large drops in the quantities of these compounds in the hot preparation of OAC Kent soymilk compared to the cold preparation of OAC Kent soymilk (data not shown). It is noteworthy that OR297, the LLA.3lx line, had the lowest lipid oxidation activity of all the cold produced soymilk samples, thus suggesting improved oxidative stability (although there were no significant differences among the cold samples). 


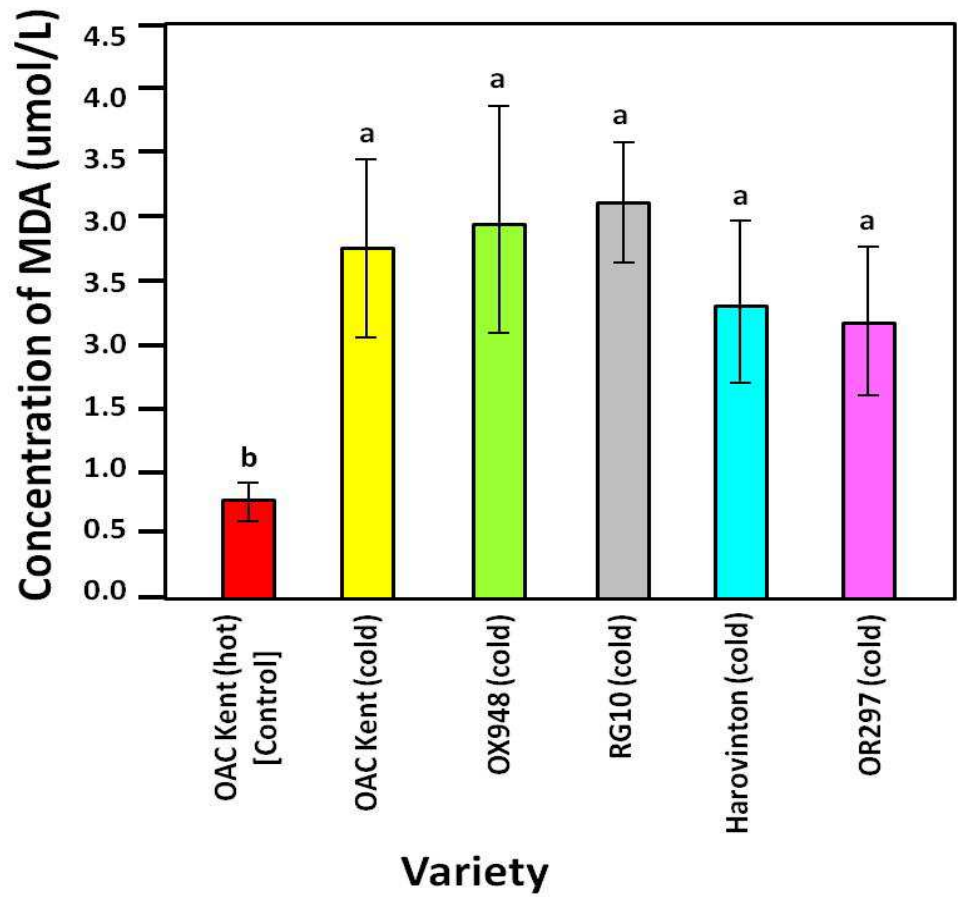

Fig. 2. Lipid oxidation activity, measured as $\mu \mathrm{mol} / \mathrm{L}$ of malondialdehyde (MDA) in soymilk samples made from OAC Kent (hot method), OAC Kent (cold method), Harovinton (cold method), OX948 (cold method), RG10 (cold method), and OR297 (cold method) at $\mathrm{t}=0 \mathrm{hrs}$ (time of preparation) and $20.5 \mathrm{hrs}$ (time of service to panelists) averaged over 4 repetitions. Cultivars/lines identified by the same letter are not significantly different at $\mathrm{p}=0.05 ; \mathrm{t}=0$ hrs series identified by uppercase letters, $t=20.5$ hrs series identified by lowercase letters.

\subsubsection{Relationship between lipid oxidation and taste in soymilk}

Correlation and regression analyses were performed using the 3-week averaged ranks for a number of taste descriptors and composition measurements. These analyses revealed that the taste panel was discriminating and reliable. For example, all the panelists could distinguish between the hot and cold preparations of OAC Kent soymilk (data not shown). In addition, the sensory evaluation for sweetness was highly correlated with the measured free sugar levels in the samples (Figure 3). Interestingly, a positive correlation between the MDA levels in the soymilk samples and their rancidity rankings $(r=0.81, p=0.05$; Figure 3$)$ was determined, thus verifying the connection between the improvement in flavour and reduction in lipid oxidation.

For most taste test descriptors, OR297 was more preferred than its parents OX948 and RG10, or Harovinton, a standard tofu cultivar, although statistical significance was lacking in some cases. In many instances, the ranking of OR297 was similar to the ranking of OAC Kent (hot method), which was included as a low lipid oxidation sample. These finding suggests that the reduction in LA and the removal of LX produced a detectable difference in terms of soymilk flavour and use of this material would improve soymilk flavour to the consumer. 


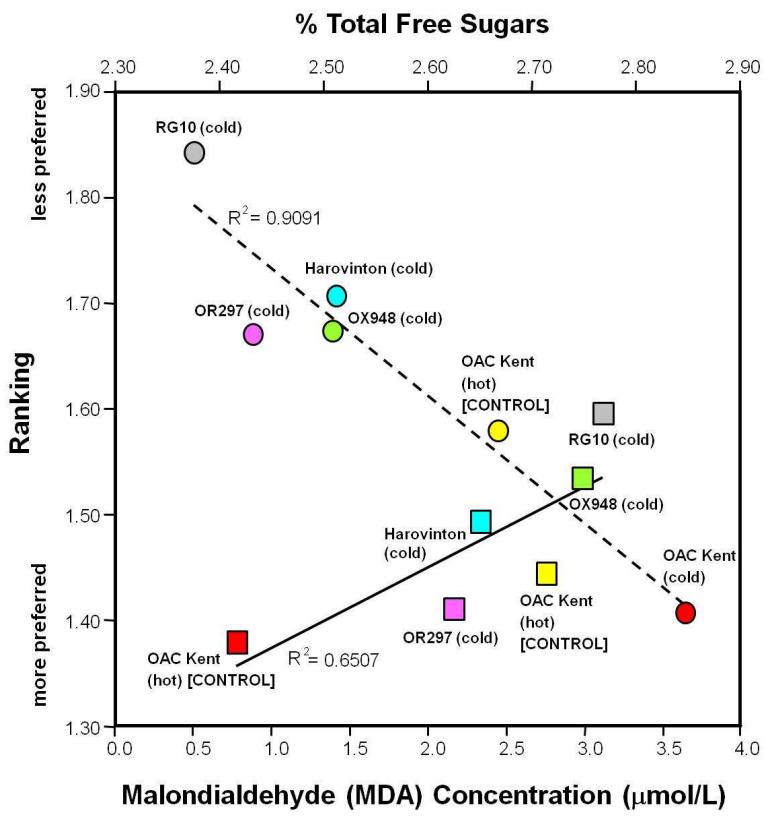

Fig. 3. Regressions for ranking for the rancid taste test descriptor on malondialdehyde

(MDA) concentration ( $\mu \mathrm{mol} / \mathrm{L})$ in the soymilk samples (- ( not labeled) at $\mathrm{t}=20.5$ hrs and for the ranking for the sweet taste test descriptor on \% total free sugars in the soymilk samples (- - - - - ). The rankings for the taste descriptors were determined by 28 panelists over 3 evaluation sessions with unlabeled samples prepared $20.5 \mathrm{hrs}$ previously.

\subsection{Use of RILs from the RG10 x OX948 cross to identify QTL for bioproduct manufacture}

The $\mathrm{F}_{5}$-derived RILs from the RG10 x OX948 cross are being used to identify genes that contribute to soybean fiber performance in composites, develop fiber gene-specific markers and map Quantitative Trait Loci (QTL) for fiber traits.

\subsubsection{Stem fiber genes and markers}

To identify fiber genes, we were using a candidate gene approach and a microarray based screen. These two approaches complement each other. The availability of cell wall gene sequences from numerous plant databases to design PCR primers makes a candidate gene approach attractive for relatively fast (and cheap) development of gene-specific markers. Moreover, the availability of the whole soybean genome sequence facilitates the development of a fiber gene in silico (sequence) map. Alternatively, the soybean oligo array, developed from 80 libraries and different tissues by University of Illinois, contains approximately 38,000 genes. Hybridization with DNA or total RNA can potentially identify many single feature polymorphism (SFP) markers or expressed QTL (eQTL), simultaneously. However, the microarray approach is more expensive (cost of array and hybridization) and more complex (work and data analysis). For the RNA work, sample preparations from stems at different stages of development would be necessary. 
Databases (NCBI, DFCI, SoyBase and Maizewall) and microarray literature were searched for genes associated with the cell wall biosynthesis and modification (cellulose, hemicellulose, pectin and lignin biosynthesis, cell wall proteins, modifying enzymes and regulatory proteins). Over 100 candidate genes were selected and more than 200 gene-based primers were designed and tested with genomic DNA of parents (RG10 and OX948) of a RIL mapping population. The majority of the PCR products were monomorphic and required an additional sequencing step to develop SNP markers. An example of a peroxidase (involved in monolignol polymerization) STS marker is shown in Fig. 4.

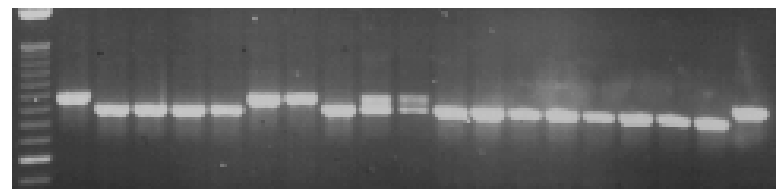

Fig. 4. Segregation pattern of peroxidase (Pox1148) STS marker

Currently, more than 30 gene-specific STS and SNP markers for key enzymes in lignin (PAL2, NAD, and LAC), hemicellulose (XE776), cellulose (CesA3, COBL4) and pectin (PECLYca) biosynthetic pathways as well as regulatory proteins (LIM1, IFL1, KNAT7 and ATHB8) were developed using the candidate gene approach. Some of the fiber genes were placed on the existing RG10 x OX948 linkage map (Reinprecht et al., 2006b). Figure 5 shows partial alignment of linkage map (right) and in silico (sequence) map (left). Only chromosomes with (currently) mapped fiber genes were shown. The soybean fiber gene in silico map was developed by blasting all gene sequences used to design primers against soybean genome. Peroxidase (Pox1148, lignin biosynthesis) was mapped on chromosome Gm09 (LG K) and glycine-rich protein (GRP) mapped on Gm12 (LG H). Transcription factor NST2 and 4-coumarate: CoA ligase 2 (4CL2, which activates hydroxycinamic acids involved in flavonoid and lignin biosynthesis) mapped on Gm13 (LG F). 4CL2 was placed close to a height QTL for the RILs in the population. Laccase (LAC, a polyphenoloxidase) and COBRA homolog COBL4 (which plays a role in cellulose deposition) were mapped on Gm18 (LG G). LAC was placed close to previously mapped height and lodging QTL. Cinnamyl alcohol dehydrogenase (CAD, lignin biosynthesis) was mapped on Gm10 (LG I) (Fig. 5).

It has been estimated that over 1000 genes might be involved in cell wall biosynthesis and modification and a microarray was also used to identify additional fiber genes and develop SFP markers. A soybean oligo microarray was hybridized with the genomic DNA of parents or RILs and RNA from stem tissue. Based on differences in signal intensity between parental (RG10 and OX948) DNA hybridizations, SFP markers for 164 candidate genes were detected. A number of these genes code for proteins with unknown functions. However, some of the genes encode cell wall biosynthesis/modification proteins (such as: ABC transporter, expansin or callose synthase) or regulatory proteins (such as: MYB109, MYB128 or MYR1) (Table 4) (Reinprecht et al., 2010. After verification, these SFPs will be mapped.

Based on the initial results, it seems feasible to use comparative genomic hybridization $(\mathrm{CGH})$ of DNA from high and low height/lodging soybean genotypes to a spotted 70-mer oligonucleotide microarray to map candidate genes for stem cell wall components in soybean and test their associations with fiber quality QTL. The advantage of this procedure is that the genetic constitution of the parents (RG10 and OX948) was obtained with only a few arrays and a short list of candidate genes was quickly generated. 
A Versatile Soybean Recombinant Inbred Line Population Segregating for

\begin{tabular}{cccc}
\hline Number & $\begin{array}{c}\text { GenBank } \\
\text { accession }\end{array}$ & Annotation & $\begin{array}{c}\text { Signal intensity } \\
\text { ratio (RG10/OX948) }\end{array}$ \\
\hline 1 & BE805115 & A. thaliana transcription factor Z46606 & 2513.8 \\
13 & BU549808 & G. max MYB transcription factor MYB109 & 164.8 \\
15 & BG509363 & S. polyrhiza PDR5-like ABC transporter & 149.5 \\
24 & BU981652 & G. barbadense fiber protein Fb11 & 52.9 \\
25 & BU550544 & R. communis polygalacturonase-like protein & 52.1 \\
41 & BE821186 & P. cerasus expansin (EXP2) & 24.6 \\
45 & BU550921 & V. vinifera similar to Callose synthase 10 & 21.2 \\
47 & BE474044 & C. sinensis hexokinase & 19.2 \\
55 & BE800964 & A. thaliana MYR1 (Myb-related protein1) & 14.2 \\
64 & BU544938 & G. max MYB transcription factor MYB 128 & 11.5 \\
160 & BU550857 & T. majus mRNA for $\alpha$-D-xylosidase & 2.5 \\
\hline
\end{tabular}

Table 4. Microarray-based (genomic DNA) candidate fiber genes and potential SFP markers (partial list)

\subsubsection{Fiber trait characterization and QTL mapping}

Fifty RILs (selected on the basis of a height/lodging index) and parents (RG10 and OX948) were evaluated (selective phenotyping) in controlled (growth room) and field environments (Harrow, Ridgetown and Woodstock in 2008 and 2009). Mature stems were collected, ground in a Wiley mill (Arthur Thomas Co., Philadelphia, Penn.) to pass a $2.0 \mathrm{~mm}$ screen and stored at $-20^{\circ} \mathrm{C}$ for further fiber characterization. Selection and optimization of protocols for determination of fiber chemical, physical and functional properties were performed on the parents (RG10 and OX948).

Thermal degradation profiles of stem fibers are affected by variation in the chemical composition of the stem material because different cell wall components have different thermal behaviours. Thermogravimetric analysis (TGA) was performed with the TGA Q500 instrument (TA Instruments, New Castle, DE) by heating RG10 and OX948 stem samples from ambient temperature to $600^{\circ} \mathrm{C}$ at heating rate of $20{ }^{\circ} \mathrm{C} / \mathrm{min}$ in a nitrogen environment. Under these conditions, RG10 and OX948 had similar degradation characteristics. Stems (untreated containing $\sim 4 \%$ moisture) started to decompose at $187^{\circ} \mathrm{C}$ in both parental lines, which is lower than untreated soybean hulls, which decompose at $209^{\circ} \mathrm{C}$ (Alemdar \& Sain, 2008). In addition, about $34 \%$ of the carbonaceous material in the stems remained after heating to $600^{\circ} \mathrm{C}$. The amount of lignocellulosic materials in RG10 and OX948 stems could not be assessed with the current TGA conditions. In both lines, hemicellulose $\left(230^{\circ} \mathrm{C}\right)$, cellulose $\left(325^{\circ} \mathrm{C}\right)$ and lignin $\left(150-600^{\circ} \mathrm{C}\right)$ degradation resulted in a broad peak with a number of shoulders (Fig. 6).

Fourier transform spectroscopy (FTIR) was performed with the Nicolet 6700 FTIR spectrometer (Thermo Fischer Scientific, Waltham, MA). The data were processed by the Omnic software (version 8.0) and recorded in the transmittance mode as a function of wavenumber after air background subtraction. FTIR spectra of each sample were obtained in the range of $4000-400 \mathrm{~cm}^{-1}$. FTIR analysis was useful to distinguish parental genotypes. Several polysaccharide peaks dominate in the FTIR spectra of RG10 and OX948 stems (Fig. 7) and parental lines show differences in intensities for major peaks in the lignin and 

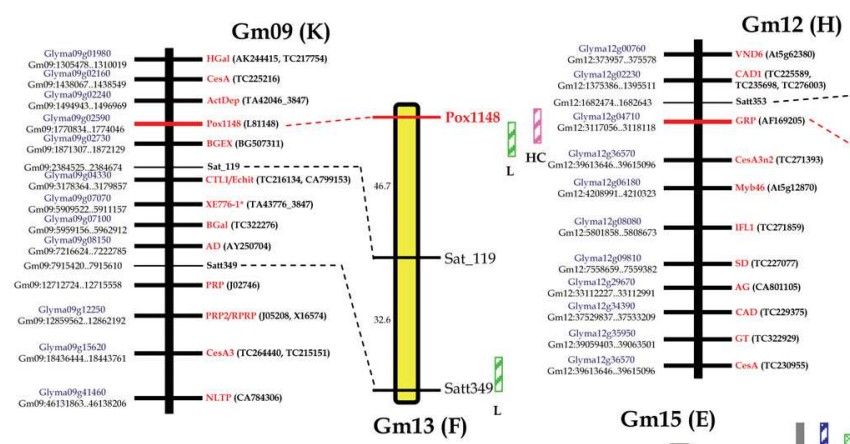

Gm14 (B2)
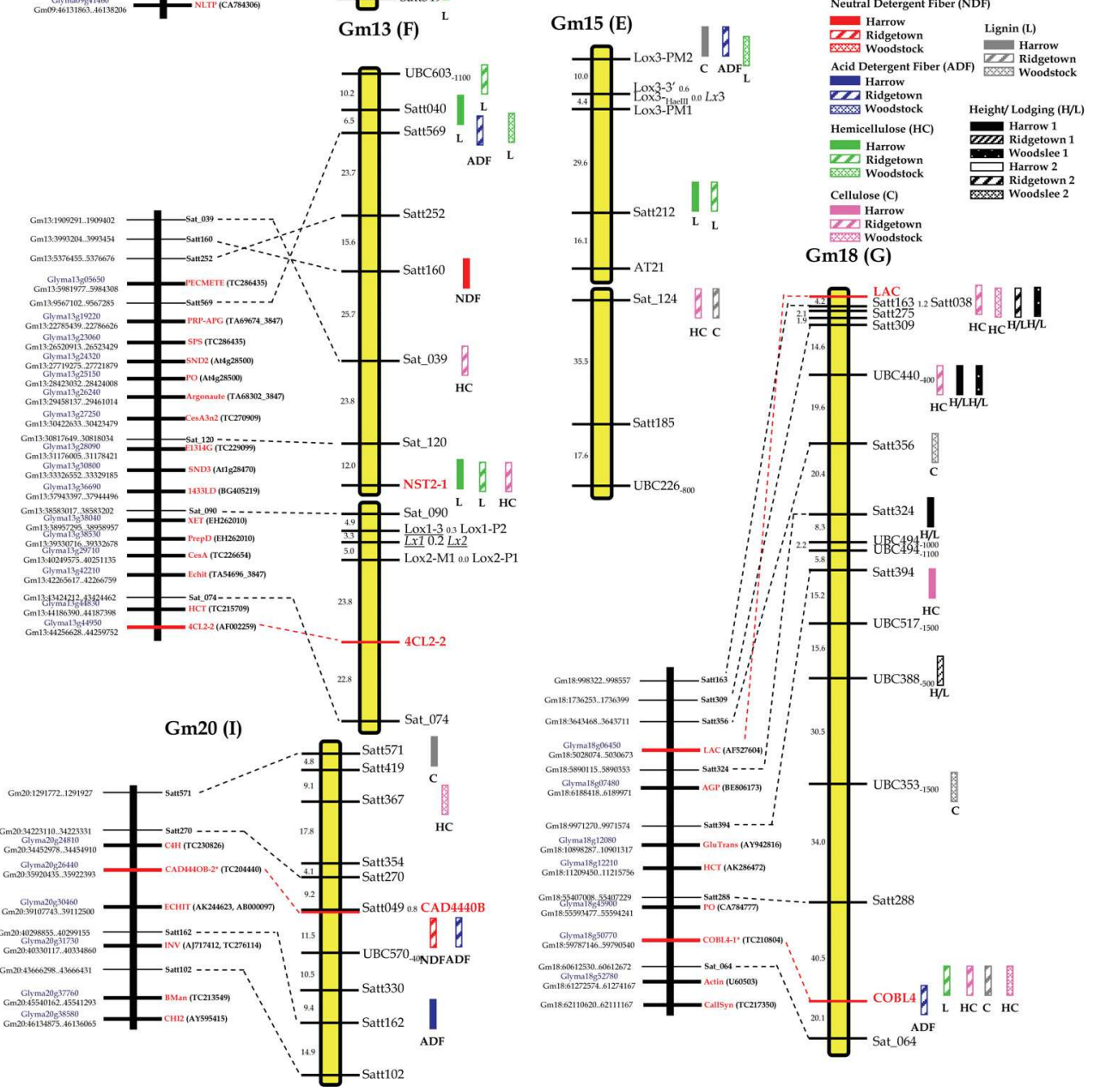

Fig. 5. The alignment of RG10 x OX948 linkage/QTL map (right) with an in silico (sequence) map (left). Fiber genes are labelled in red. 


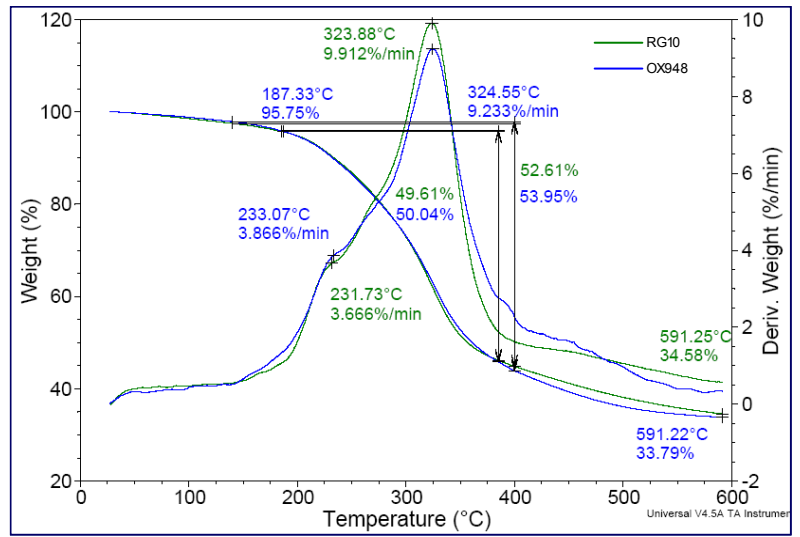

Fig. 6. TGA thermograms of RG10 and OX948 stems heated at $20^{\circ} \mathrm{C} / \mathrm{min}$

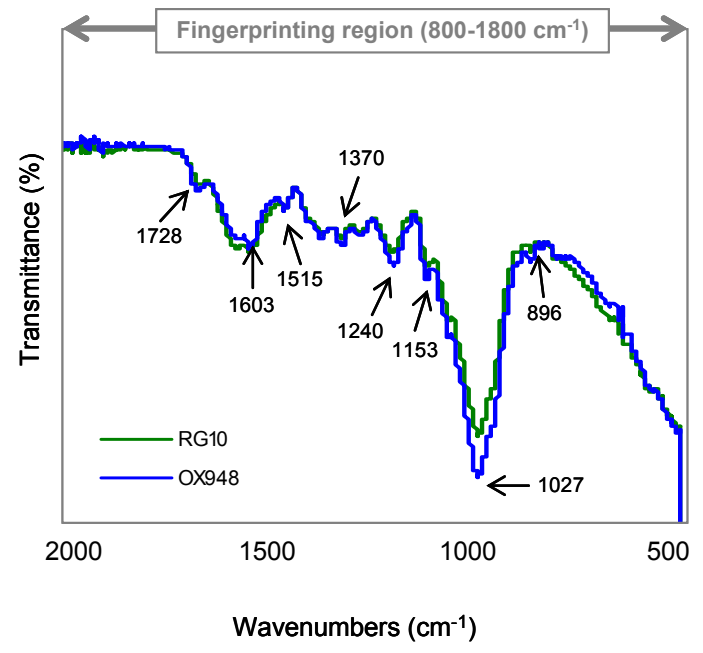

Fig. 7. FTIR spectra of RG10 and OX948 stems

polysaccharide spectral regions (peaks at 896, 1027, 1240 and 1632 wavenumbers) that indicate that quantitative (peak area) FTIR analysis might be a suitable technique to determine amount of lignocellulosic material in soybean stems.

Stems were characterized for neutral detergent fibers [NDF, isolates (grass) cell wall (hemicellulose, cellulose and lignin)], acid detergent fibers (ADF, isolates cellulose and lignin) and acid detergent lignin (ADL, isolates lignin) using sequential analysis with the Ankom 200 fiber anlyzer (Ankom technology, Macedon, NY). Hemicellulose and cellulose content were calculated from NDF, ADF and ADL values (hemicellulose $=$ NDF - ADF, cellulose $=$ ADF - ADL). Soybean stem contains approximately $289 \mathrm{~g} \mathrm{~kg}^{-1}$ hemicellulose, 526 $\mathrm{g} \mathrm{kg}^{-1}$ cellulose and $173 \mathrm{~g} \mathrm{~kg}^{-1}$ lignin (Johnson et al., 2007). The stems of RILs grown in three locations in 2008 contained an average of $365 \mathrm{~g} \mathrm{~kg}^{-1}$ cellulose (range 263-454), $173 \mathrm{~g} \mathrm{~kg}^{-1}$ hemicellulose (range 123-220) and $119 \mathrm{~g} \mathrm{~kg}^{-1}$ lignin (range 32-169). Significant negative 
correlations were detected between lignin and cellulose and lignin and hemicellulose, while cellulose and hemicellulose were positively correlated (Table 5). In addition, lignin content was positively correlated with the height/lodging index trait (data not shown).

\begin{tabular}{|c|c|c|c|c|c|c|c|c|c|}
\hline \multirow{3}{*}{ Location } & \multirow{3}{*}{ Trait } & \multicolumn{8}{|c|}{ Location (2008) } \\
\hline & & \multicolumn{3}{|c|}{ Harrow } & \multicolumn{3}{|c|}{ Ridgetown } & \multicolumn{2}{|c|}{ Woodstock } \\
\hline & & Lignin & Hemicellulose & Cellulose & Lignin & Hemicellulose & Cellulose & Lignin & Hemicellulose \\
\hline \multirow{2}{*}{ Harrow } & Hemicellulose & 0.26 & & & & & & & \\
\hline & Cellulose & $-0.61^{* *}$ & -0.01 & & & & & & \\
\hline \multirow{3}{*}{ Ridgetown } & Lignin & 0.37 & 0.26 & -0.30 & & & & & \\
\hline & Hemicellulose & -0.02 & 0.10 & 0.01 & 0.21 & & & & \\
\hline & Cellulose & -0.10 & -0.08 & 0.40 & $-0.54^{* *}$ & -0.32 & & & \\
\hline \multirow{3}{*}{ Woodstock } & Lignin & 0.01 & 0.15 & -0.01 & -0.01 & 0.14 & 0.10 & & \\
\hline & Hemicellulose & 0.13 & 0.06 & 0.10 & 0.02 & -0.14 & 0.18 & $-0.40^{* *}$ & \\
\hline & Cellulose & 0.08 & 0.23 & 0.09 & $0.60^{* * *}$ & 0.18 & -0.32 & -0.20 & 0.11 \\
\hline
\end{tabular}

Table 5. Correlations among cellulose, hemicellulose and lignin content in soybean stems across different locations

Fifteen stem fiber QTL were detected in Harrow, 33 in Ridgetown and 13 in Woodstock in 2008. Some QTL were associated with fiber genes. For example, a lignin QTL on chromosome Gm09 (LG K) was linked to the peroxidase gene Pox1148 (monolignol polymerization) while a cellulose QTL on Gm18 (LG G) was associated with the COBRA homolog gene COBL4, which is involved in cellulose biosynthesis (Fig. 5).

\section{Conclusions}

This chapter describes development of a versatile soybean RIL population segregating for LLA and $1 \times 3$, its molecular characterization and utility for soymilk and composite material production. The $169 \mathrm{~F}_{5}$-derived RILs from the RG10 x OX948 cross are well characterized for numerous seed, agronomic and stem fiber traits. In addition to the LA and LX traits, the population is segregating for a number of other traits, including: seed traits [such as: other fatty acids (palmitic, steraic, oleic and linoleic), oil and protein content]; developmental traits (such as: flowering, maturity, lodging, plant height and height/lodging index); seed weight and yield and stem fiber traits (such as: cellulose, hemicellulose and lignin content). QTL for these traits were placed on a RG10 x OX948 linkage/QTL map and their relationships were determined. A number of these QTL were stable across many environments so that the markers associated with them would likely be useful for MAS. In the future, the addition of new markers will saturate map and help us to determine whether the regions significant for more than one trait reflect pleiotropy or gene linkage.

The molecular bases of LLA in RG10 and 1x3 in OX948 as well as six LLA.31x RILs (RO115, RO162, OR265, OR297, OR315 and OR322) were determined. The LLA trait in RG10 is caused by the mutation in two Fad3 genes (Fad3A and Fad3B). The 1x3 trait in OX938 is caused by mutations in all three LX genes. The novel LLA.31x RILs contain all five mutated alleles (fanfan-blx1lx2lx3), which resulted in low levels of LA and lack of all three LX in the seed. When these lines were compared with lines combining high LA and all three LX present, no yield difference between the two groups of lines was detected suggesting that it should be possible to use this novel germplasm to develop competitive soybean cultivars that are resistant to oxidative degradation. 
The simple and independent inheritance of LA and seed LX in RG10 x OX948 crosses should simplify breeding for soybean cultivars that are resistant to oxidative degradation. Acceleration and further simplification of breeding for soybean with improved flavour could be accomplished by using molecular markers. Markers developed for mutations in two $\omega-3$ fatty acid desaturase (Fad3A and Fad3B in RG10) and three LX (Lx1, Lx2 and Lx3 in OX948) genes will allow more accurate selection for LLA and 3lx phenotypes based on DNA screens rather than relying on phenotypic expression. Some of the markers were already successfully used in MAS for soybean with improved flavour.

Soymilk prepared from OR297 (LLA.31x), OX948 (31x), RG10 (LLA), Harovinton (tofu-type) and OAC Kent (oilseed type) were evaluated by a sensory panel. Generally, OR297 was the most preferred and a significant relationship between rancidity and lipid oxidation levels was identified.

Although, work on soybean stem fibers is still in progress, a number of genes coding for key enzymes in cell wall biosynthesis and modification were identified. Markers were developed and some fiber traits were characterized and mapped. When completed, this work will allow identification of key factors in fiber quality and development of quick, marker-based screening method(s) to allow rapid introgression of genes for good fiber quality into elite soybean cultivars. It would be possible to create agriculturally-acceptable cultivars with good fiber performance characteristics in composites such as cultivars with higher cellulose content for products requiring higher strength and modulus, with higher lignin content when higher extensibility of products is needed, or cultivars with reduced hemicellulose content to achieve higher processing temperatures of biocomposites. Furthermore, the newly available sequence information can be used to characterize fiber gene mutations at molecular level.

Different combinations of seed, agronomic and stem fiber traits in RILs derived from the RG10 x OX948 cross, and the availability of a linkage/QTL map and correlations among traits could be further exploited to develop novel or specialty soybeans, both for food and industrial applications. The population is available for research purposes.

\section{References}

Alemdar, A. \& Sain, M. (2008). Isolation and characterization of nanofibers from agricultural residues - Wheat straw and soy hulls. Bioresource Technology, Vol., 99, (April 2008) 1664-1671

Anai, T.; Yamada, T.; Kinoshita, T.; Rahman, S.M. \& Takagi, Y. (2005). Identification of corresponding genes for three low-a-linolenic acid mutants and elucidation of their contribution to fatty acid biosynthesis in soybean seed. Plant Science, Vol., 168, (June 2005) 1615-1623

Axelrod, B.; Cheesebourgh, T.M. \& Laakso, C. (1981). Lipoxygenase from soybeans. Methods in Enzymology, Vol., 71, (1981) 441-451

Bannon, C. D.; Craske, J.D.; Felder, D.L.; Garland, I.J. \& Norman, L.M. (1987). Analysis of fatty acid methyl esters with accuracy and reliability. VI. Rapid analysis by split injection capillary gas-liquid chromatography. Journal of Chromatography, Vol., 407, (October 1987) 231-241

Bilyeu, K. D.; Palavalli, L.; Sleper, D.A. \& Beuselinck, P.R. (2003). Three microsomal omega-3 fatty-acid desaturase genes contribute to soybean linolenic acid levels. Crop Science, Vol., 43, (September 2003) 1833-1838 
Bilyeu, K.; Palavalli, L.; Sleper, D. \& and Beuselinck, P.R. (2005). Mutations in soybean microsomal omega-3 fatty acid desaturase genes reduce linolenic acid concentration in soybean seeds. Crop Science, Vol., 45, (August 2005) 1830-1836

Bilyeu, K.; Palavalli, L.; Sleper, D.A. \& Beuselinck, P.R. (2006). Molecular genetic resources for development of $1 \%$ linolenic acid soybean. Crop Science, Vol., 46, (September 2006) 1913-1918

Boerjan, W.; Ralph. J. \& Baucher, M. (2003). Lignin biosynthesis. Annual Review of Plant Biology, Vol., 54, (June 2003) 519-546

Brummer, E.C.; Nickell, A.D.; Wilcox, J.R. \& Shoemaker, R.C. (1995). Mapping the Fan locus controlling linolenic acid content in soybean oil. Journal of Heredity, Vol., 86, (May 1995) 245-247

Buege, J.A. \& Aust, S.D. (1978). Microsomal lipid peroxidation. Methods in Enzymoogy, Vol., 52, (1978) 302-310

Byrum, J. R.; Kinney, A.J.; Shoemaker, R.C. \& Diers, B.W. (1995). Mapping of the microsomal and plastid omega-3 fatty acid desaturases in soybean [Glycine max (L.) Merr.]. Soybean Genetics Newsletter, Vol., 22, (1995) 181-184

Byrum, J. R.; Kinney, A.J.; Stecca, K.L.; Grace, D.J. \& Diers, B.W. (1997). Alteration of the omega-3 fatty acid desaturase gene is associated with reduced linolenic acid in the A5 soybean genotype. Theoretical and Applied Genetics, Vol., 94, (March 1997) 356359

Chappel, A. S. \& Bilyeu, K.D. (2006). A GmFAD3A mutation in the low linolenic acid soybean mutant C1640. Plant Breeding, Vol., 125, (December 2006) 535-536

Cherif, A.; Dubacq, J.P.; Mache, R.; Oursel, A. \& Tremolieres, A. (1975). Biosynthesis of $\alpha-$ linolenic acid by desaturation of oleic and linoleic acids in several organs of higher and lower plants and in algae. Phytochemistry, Vol., 14, (March 1975) 703-706

Davies, C.S. \& Nielsen, N.C. (1986). Genetic analysis of a null-allele for lipoxygenase-2 in soybean. Crop Science, Vol., 26, (May-June 1986) 460-463

Davies, C.S.; Nielsen, S.S. \& Nielsen, N.C. (1987). Flavor improvement of soybean preparations by genetic removal of lipoxygenase-2. Journal of the American Oil Chemists' Society, Vol., 64, (October 1987) 1428-1433

Dutton, H.J.; Lancaster, C.R.; Evans, C.D. \& Cowan, J.C. (1951). The flavour problem of soybean oil. VIII. Linolenic acid. Journal of the American Oil Chemists' Society, Vol., 28, (March 1951) 115-118

Fehr, W.R.; Welke, G.A.; Hammond, E.G.; Duvick, D.N. \& Cianzio, S.R. (1992). Inheritance of reduced linolenic acid content in soybean genotypes A16 and A17. Crop Science, Vol., 32, (July 1992) 903-906

Feussner, I. \& Wasternack, C. (2002). The lipoxygenase pathway. Annual Review of Plant Biology, Vol., 53, (2002) 275-297

Furata, S.; Nishiba, Y.; Hajika, M.; Igita, K. \& Suda, I. (1996). DETBA value and hexanal production with the combination of unsaturated fatty acids and extracts prepared from soybean seeds lacking two or three lipoxygenase isozymes. Journal of Agricultural and Food Chemistry, Vol., 44, (January 1996) 236-239

Graef, G.L.; Fehr, W.R.; Miller, L.A.; Hammond, E.G. and Cianzio, S.R. (1988). Inheritance of fatty acid composition in a soybean mutant with low linolenic acid. Crop Science, Vol., 28, (January-February 1988) 55-58

Hajika, M.; Igita, K. \& Kitamura, K. (1991). A line lacking all the seed lipoxygenase isozymes in soybean [Glycine max (L.) Merrill] induced by gamma-ray irradiation. Japanese Journal of Breeding, Vol., 41, (1991) 507-509 
Hajika, M.; Kitamura, K.; Igita, K. \& Nakazawa, Y. (1992). Genetic relationships among the genes for lipoxygenase-1, -2 and -3 isozymes in soybean [Glycine max (L.) Merrill] seed. Japanese Journal of Breeding, Vol., 42, (1992) 787-792

Hammond, E.G.; Fehr, W.R. \& Snyder, H.E. (1972). Improving soybean quality by plant breeding. Journal of the American Oil Chemists' Society, Vol., 49, (January 1972) 33-35

Hartholt, J.; Suttangkakul, A. \& Scheller, H.V. (2010). Biosynthesis of pectin. Plant physiology, Vol., 153, (June 2010) 384-395

Hayakawa, K.; Linko, Y \& Linko, P. (2000). The role of trans fatty acids in human nutrition. European Journal of Lipid Science and Technology, Vol., 102, (June 2000) 419-425

Hildebrand, D.F. \& Hymowitz, T. (1981). Two soybean genotypes lacking lipoxygenase-1. Journal of the American Oil Chemists' Society, Vol., 58, (May 1981) 583-586

Hildebrand, D.F. \& Hymowitz, T. (1982). Inheritance of lipoxygenase-1 activity in soybean seeds. Crop Science, Vol., 22, (July-August 1982) 851-853

Hodges, D.M.; DeLong, J.M.; Forney, C.F. \& Prange, R.K. (1999). Improving the thiobarbituric acid-reactive-substances assay for estimating lipid peroxidation in plant tissues containing anthocyanin and other interfering compounds. Planta, Vol., 207, (February 1999) 604-611

Johnson, J. M.-F.; Barbour, N.W. \& Lachnicht Weyers, S. (2007). Chemical composition of crop biomass impacts its decomposition. Soil Science Society of America Journal, Vol., 71, (January-February 2007) 153-162

Kim, M.Y.; Ha, B.-K.; Jun, T.-H.; Hwang, E.-Y.; Van, K.; Kuk, Y.I. \& Lee, S.-H. (2004). Single nucleotide polymorphism discovery and linkage mapping of lipoxygenase-2 (Lx2) in soybean. Euphytica, Vol., 135, (February 2004) 169-177

King, J.M.; Svendsen, L.K.; Fehr, W.R.; Narvel, J.M. \& White, P.J. (1998). Oxidative and flavor stability of oil from lipoxygenase-free soybeans. Journal of the American Oil Chemists' Society, Vol., 75, (September 1998) 1121-1126

Kitamura, K.; Davies, C.S.; Kaizuma, N. \& Nielsen, N.C. (1983). Genetic analysis of a nullallele for lipoxygenase-3 in soybean seeds. Crop Science, Vol., 23, (SeptemberOctober 1983) 924-927

Kitamura, K. (1984). Biochemical characterization of lipoxygenase lacking mutants, L-1-less, L-2-less, and L-3-less soybeans. Agricultural and Biological Chemistry, Vol., 48, (1984) 2339-2346

Kitamura, K.; Kumagai, T. \& Kikuchi, A. (1985). Inheritance of lipoxygenase-2 and genetic relationships among genes for lipoxygenase-1, -2 and -3 isozymes in soybean seeds. Japanese Journal of Breeding, Vol., 35, (1985) 413-420

Kitamura, K. (1993). Breeding trials for improving the food-processing quality of soybeans. Trends in Food Science and Technology, Vol., 4, (March 1993) 64-67

Kobayashi, A.; Tsuda, Y.; Hirata, N.; Kubota, K. \& Kitamura, K. (1995). Aroma constituents of soybean [Glycine max (L.) Merril] milk lacking lipoxygenase isozymes. Journal of Agricultural and Food Chemistry, Vol., 43, (September 1995) 2449-2452

Kosambi, D.D. (1944). The estimation of map distances from recombination values. Annals of Eugenics, Vol., 12, (1944) 172-175

Lander, E.S.; Green, P.; Abrahamson, J.; Barlow, A.; Daly, M.J.; Lincoln, S.E. \& Newburg, L. (1987). MAPMAKER: An interactive computer package for constructing primary linkage maps of experimental and natural populations. Genomics, Vol., 1, (October 1987) $174-181$

Lenis, J.M.; Gillman, J.D.; Lee, J.D.; Shannon, J.G. \& Bilyeu, K.D. (2010). Soybean seed lipoxygenase genes: molecular characterization and development of molecular marker assays. Theoretical and Applied Genetics, Vol., 120, (April 2010) 1139-1149 
Lindstrom, M.J. (1986). Effects of residue harvesting on water runoff, soil erosion and nutrient loss. Agriculture, Ecosystems and Environment, Vol., 16, (June 1986) 103-112

Liu, K. (1997). Soybeans: chemistry, technology, and utilization. Chapman \& Hall, ISBN 0-41208121-0, New York, NY

Luk, S. (2006). Developing low linolenic acid lipoxygenase-free soybean lines for improved soymilk stability and flavour. M.Sc. Dissertation, University of Guelph

Martin, B.A.; Carver, B.F.; Burton, J.W. \& Wilson, R.F. (1983). Inheritance of fatty acid composition in soybean seed oil. Soybean Genetics Newsletter, Vol., 10, (1983) 89-92

Mohnen, D. (2008). Pectin structure and biosynthesis. Current Opinion in Plant Biology, Vol., 11, (June 2008) 266-277

Mohnen, D.; Bar-Peled, L. \& Somerville, C. (2008). Cell wall synthesis, In: Biomass Recalcitrance: Deconstruction the Plant Cell Wall for Bioenergy, Himmel, M.E. (Ed.), 94187, Wiley-Blackwell, ISBN 1405163607, Oxford

Mounts, T.L.; Warner, K.; List, G.R.; Kleiman, R.; Fehr, W.R.; Hammond, E.G. \& Wilcox, J.R. (1988). Effect of altered fatty acid composition on soybean oil stability. Journal of the American Oil Chemists' Society, Vol., 65, (May 1988) 624-628

Mounts, T.L.; Warner, K.; List, G.R.; Neff, W.E. \& Wilson, R.F. (1994). Low-linolenic acid soybean oils - alternatives to frying oils. Journal of the American Oil Chemists Society, Vol., 71, (May 1994) 495-499

Mutwil, M.; Debolt, S. \& Persson, S. (2008). Cellulose synthesis: a complex complex. Current Opinion in Plant Biology, Vol., 11, (June 2008) 252-257

Pedersen, T.C.; Buege, J.A. \& Aust, S.D. (1973). Microsomal electron transport. Journal of Biological Chemistry, Vol., 248, (October 1973) 7134-7141

Penning, B.W.; Hunter III, C.T.; Tayengwa, R.; Eveland, A.L.; Dugard, C.K.; Olek, A.T.; Vermerris, W.; Koch, K.E.; McCarty, D.R.; Davis, M.F.; Thomas, S.R.; McCann, M.C. \& Carpita, N.C. (2009). Genetic resources for maize cell wall biology. Plant Physiology, Vol., 151, (December 2009) 1703-1728

Rackis, J.J.; Sessa, D.J. \& Honig, D.H. (1979). Flavour problems of vegetable food proteins. Journal of the American Oil Chemists' Society, Vol., 56, (March 1979) 262-271

Rahman, S.M.; Kinoshita, T.; Anai, T.; Arima, S. \& Takagi, Y. (1998). Genetic relationships of soybean mutants for different linolenic acid contents. Crop Science, Vol., 38, (September 1998) 702-706

Reinprecht, Y. (2002). Investigation of genetic and molecular basis of low linolenic acid, lipoxygenase-free soybean [Glycine max (L.) Merrill]. PhD. Dissertation, University of Guelph

Reinprecht, Y.; Rajcan, I.; Poysa, V. W.; Ablett, G. R. \& Pauls, K.P. (2005). Relationships and inheritance of linolenic acid and seed lipoxygenases in soybean crosses designed to combine these traits. Canadian Journal of Plant Science Vol., 85, (July 2005) 593-602

Reinprecht, Y.; Poysa, V. W.; Rajcan, I.; Ablett, G. R. \& Pauls, K.P. (2006a). Agronomic performance of soybean with seed lipoxygenase nulls and low linolenic acid content. Canadian Journal of Plant Science Vol., 86, (April 2006) 379-287

Reinprecht, Y.; Poysa, V. W.; Yu, K.; Rajcan, I.; Ablett, G. R. \& Pauls, K.P. (2006b). Seed and agronomic QTL in low linolenic acid, lipoxygenase-free soybean (Glycine max (L.) Merrill) germplasm. Genome, Vol., 49, (December 2006) 1510-1527

Reinprecht, Y.; Luk-Labey, S.; Larsen, J.; Poysa, V. W.; Yu, K.; Rajcan, I.; Ablett, G. R. \& Pauls, K.P. 2009. Molecular basis of the low linolenic acid trait in soybean EMS mutant line RG10. Plant Breeding, Vol., 128, (June 2009) 253-258

Reinprecht, Y.; Ablet, G. R.; Poysa, V. W.; Rajcan, I. \& Pauls, K.P. (2010). Soybean residue for the auto industry: Genes for fiber characteristics. Proceedings of $11^{\text {th }}$ International 
Conference on Biocomposites: Transition to Green Materials, Toronto Canada, May 2010, USB (available from the authors)

Reinprecht, Y.; Luk-Labey, S.; Yu, K.; Poysa, V. W.; Rajcan, I.; Ablett, G. R.\& Pauls, K. P. (2011). Molecular basis of seed lipoxygenase null traits in soybean line OX948. Theoretical and Applied Genetics, DOI 10.1007/s00122-011-1528-5

Ross, A.J.; Fehr, W.A.; Welke, G.A. \& Cianzio, S.R. (2000). Agronomic and seed traits of 1\%linolenate soybean genotypes. Crop Science, Vol., 40, (March 2000) 383-386

Sauer, M.-L.A.; Scott, R.A \& Cheesebrough, T.M. (2008). Marker-assisted selection for low linolenic acod content in soybean. Journal of Crop Improvement, Vol., 21, (April 2008) 139-155

Scheller, H.V. \& Ulvskov, P. (2010). Hemicelluloses. The Annual Review of Plant Biology, Vol., 61, (April 2010) 263-289

Schmidt, H.; Dresselhaus, T.; Buck, F. \& Heinz, E. (1994). Purification and PCR-based cDNA cloning of plastidial n-6 desaturase. Plant Molecular Biology, Vol., 26, (October 1994) 631-642

Schmutz, J.; Cannon, S.B.; Schlueter, J.; Ma, J.; Mitros, T.; Nelson, W.; Hyten, D.L.; Song, Q.; Thelen, J.J.; Cheng, J.; Xu, D.; Hellsten, U.; May, G.D.; Yu, Y.; Sakurai, Y.; Umezawa, T.; Bhattacharyya, M.K.; Sandhu, D.; Valliyodan, B.; Lindquist, E.; Peto, M.; Grant, D.; Shu, S.; Goodstein, D.; Barry, K.; Futrell-Griggs, M.; Abernathy, B.; Du, J.; Tian, Z.; Zhu, L.; Gill, N.; Joshi, T.; Libault, M.; Sethuraman, A.; Zhang, X.-C.; Shinozaki, K.; Nguyen, H.T.; Wing, R.A.; Cregan, P.; Specht, S.; Grimwood, J.; Rokhsar, D.; Stacey, G.; Shoemaker, R.C. \& Jackson, S.A. (2010). Genome sequence of the palaeopolyploid soybean. Nature, Vol., 463, (January 2010) 178-183

Shen, N.; Fehr, W.; Johnson, L. \& White, P. (1996). Oxidative stabilities of soybean oils that lack lipoxygenases. Journal of the American Oil Chemists' Society, Vol., 73, (October 1996) 1327-1336

Shin, J.H.; Van, K.; Kim, D.H.; Kim, K.D.; Jang, Y.E.; Choi, B.-S.; Kim, M.Y. \& Lee, S.-H. (2008). The lipoxygenase gene family: a genomic fossil of shared polyploidy between Glycine max and Medicago truncatula. BMC Plant Biology, Vol., 8, (December 2008) doi:10.1186/1471-2229-8-133

Somerville, C. (2006). Cellulose Synthesis in Higher Plants. Annual Review of Cell and Developmental Biology, Vol., 22, (November 2006) 53-78

Spencer, M.M.; Landau-Ellis, D.; Meyer, E.J. \& Pantalone, V. R. (2004). Molecular markers associated with linolenic acid content in soybean. Journal of the American Oil Chemists' Society, Vol., 81, (June 2004) 1121-1126

Sticklen, M. (2006). Plant genetic engineering to improve biomass characteristics for biofuels. Current Opinion in Biotechnology, Vol., 17, (June 2006) 315-319

Sticklen, M.B. (2008). Plant genetic engineering for biofuel production: towards affordable cellulosic ethanol. Nature Review Genetics, Vol., 9, (June 2008) 433-443

Stojsin, D.; Luzzi, B.M.; Ablett, G.R. \& Tanner, J.W. (1998). Inheritance of low linolenic acid level in the soybean line RG10. Crop Science, Vol., 38, (November 1998) 1441-1444

Suda, I.; Hajika, M.; Nishiba, Y.; Furuta, S. \& Igita, K. (1995). Simple and rapid method for the selective detection of individual lipoxygenase isozymes in soybean seeds. Journal of Agricultural and Food Chemistry, Vol., 43, (March 1995) 742-747

Torres-Penaranda, A.V. \& Reitmeier, C.A. (2001). Sensory descriptive analysis of soymilk. Journal of Food Science, Vol., 66, (March 2001) 352-356

Vanholme, R.; Morreel, K.; Ralph, J. \& Boerjan, W. (2008). Lignin engineering. Current Opinion in Plant Biology, Vol., 11, (June 2008) 278-285 
Wang S.; Basten, C.J. \& Zeng, Z.-B. (2001-2004). Windows QTL Cartographer 2.0. Department of Statistics, North Carolina State University, Raleigh, NC. ( http://statgen.ncsu.edu/qtlcart/WQTLCart.htm)

Wang, W.; Takano, T.; Shibata, D.; Kitamura, K. \& Takeda, G. (1994). Molecular basis of a null mutation in soybean lipoxygenase 2: Substitution of glutamine for an ironligand histidine. Proceedings of the National Academy of Sciences USA, Vol., 91, (January 1994) 828-5832

Wang, W.; Kato, T.; Takano, T.; Shibata, D.; Kitamura, K. \& Takeda, G. (1995). Two singlebase mutations involved in altering in a paired-box of AAATAC in the promoter region of soybean lipoxygenase L-3 gene impair the promoter function in tobacco cells. Plant Science, Vol., 109, (July 1995) 67-73

White, P.J. (2000). Fatty acids in oilseeds (Vegetable oils), In: Fatty acids in foods and their health implications, Chow, C.K. (Ed.), 357-374, Marcel Dekker, ISBN 0-8247-6782-9, New York-Basel

Wilcox, J.R.; Cavins, J.F. \& Neilsen, N.C. (1984) Genetic alteration of soybean oil composition by a chemical mutagen. Journal of the American Oil Chemists' Society, Vol., 61, (January 1984) 97-100.

Wilcox, W.R. (1985). Breeding soybeans for improved oil quantity and quality. In: World soybean research conference III: Proceedings, Shibles, R. (Ed.), 380-386, Westview Press, ISBN 0-8133-0091-6, Boulder and London

Wilcox, J.R. \& Cavins, J.F. (1985). Inheritance of low linolenic acid content of the seed oil of a mutant in Glycine max. Theoretical and Applied Genetics, Vol., 71, (November 1985) 74-78

Wills, E.D. (1964) The effect of inorganic iron on the thiobarbituric acid method for the determination of lipid peroxides. Biochimica et Biophysica Acta, Vol., 84, (August 1964) $475-477$

Wilson, R.F. (1998). New commodity products from soybean through biotechnology. Oil Mill Gazetteer, Vol., 104 (1998) 27-33

Wilson, L.A. (1996). Comparison of lipoxygenase-null and lipoxygenase-containing soybeans for foods. In: Lipoxygenase and lipoxygenase pathway enzymes, Piazza, G. (Ed.), 209-225, AOCS Press, ISBN 978-0-935315-74-5, Champaign, IL.

Wolf, W.J. (1975). Lipoxygenase and flavour of soybean protein products. Journal of Agricultural and Food Chemistry, Vol., 23, (March 1975) 136-141

Wolf, R.B.; Cavins, J.F.; Kleiman, R. \& Black, L.T. (1982). Effect of temperature on soybean seed constituents: Oil, protein, moisture, fatty acids, amino acids and sugars. Journal of American Oil Chemists Society, Vol., 59, (May 1982) 230-232

Yokoyama, R. \& Nishitani, K. (2004). Genomic basis for cell wall diversity in plants. A comparative approach to gene families in rice and Arabidopsis. Plant and Cell Physiology, Vol., 45, (September 2004) 1111-1121

Zhong, R. \& Ye, Z.-H. (2007). Regulation of cell wall biosynthesis. Current Opinion in Plant Biology, Vol., 10, (October 2007) 564-572

Zhong, R.; Lee, J.; Zhou, J.; McCarthy, R.L. \& Ye, Z.-H. (2008). A Battery of transcription factors involved in the regulation of secondary cell wall biosynthesis in Arabidopsis. The Plant Cell, Vol., 20, (October 2008) 2763-2782

Zock, P.L. \& Katan, M.B. (1997). Trans fatty acids, lipoproteins, and coronary risk. Canadian Journal of Physiology and Pharmacology, Vol., 75, (March 1997) 211-216 


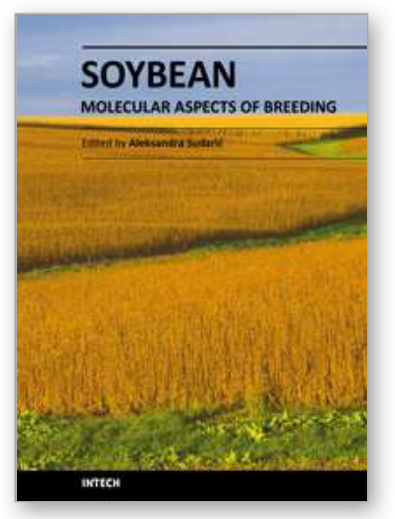

\author{
Soybean - Molecular Aspects of Breeding \\ Edited by Dr. Aleksandra Sudaric
}

ISBN 978-953-307-240-1

Hard cover, 514 pages

Publisher InTech

Published online 11, April, 2011

Published in print edition April, 2011

The book Soybean: Molecular Aspects of Breeding focuses on recent progress in our understanding of the genetics and molecular biology of soybean and provides a broad review of the subject, from genome diversity to transformation and integration of desired genes using current technologies. This book is divided into four parts (Molecular Biology and Biotechnology, Breeding for Abiotic Stress, Breeding for Biotic Stress, Recent Technology) and contains 22 chapters.

\title{
How to reference
}

In order to correctly reference this scholarly work, feel free to copy and paste the following:

Yarmilla Reinprecht, Shun-Yan Luk-Labey and K. Peter Pauls (2011). A Versatile Soybean Recombinant Inbred Line Population Segregating for Low Linolenic Acid and Lipoxygenase Nulls - Molecular Characterization and Utility for Soymilk and Bioproduct Production, Soybean - Molecular Aspects of Breeding, Dr. Aleksandra Sudaric (Ed.), ISBN: 978-953-307-240-1, InTech, Available from:

http://www.intechopen.com/books/soybean-molecular-aspects-of-breeding/a-versatile-soybean-recombinantinbred-line-population-segregating-for-low-linolenic-acid-and-lipoxy

\section{INTECH}

open science | open minds

\section{InTech Europe}

University Campus STeP Ri

Slavka Krautzeka 83/A

51000 Rijeka, Croatia

Phone: +385 (51) 770447

Fax: +385 (51) 686166

www.intechopen.com

\section{InTech China}

Unit 405, Office Block, Hotel Equatorial Shanghai

No.65, Yan An Road (West), Shanghai, 200040, China

中国上海市延安西路65号上海国际贵都大饭店办公楼405单元

Phone: +86-21-62489820

Fax: $+86-21-62489821$ 
(C) 2011 The Author(s). Licensee IntechOpen. This chapter is distributed under the terms of the Creative Commons Attribution-NonCommercialShareAlike-3.0 License, which permits use, distribution and reproduction for non-commercial purposes, provided the original is properly cited and derivative works building on this content are distributed under the same license. 